\title{
Younger Granites and Associated Pegmatites of Gabal El Fereyid - Wadi Rahaba Area, South Eastern Desert, Egypt: Geological and Geochemical Characteristics
}

\author{
Maher I. Dawoud ${ }^{1}$, Gehad M. Saleh*2, Hassan A. Shahin², Farrage M. Khaleal' and Bahaa M. Emad² \\ ${ }^{1}$ Geology Department, Faculty of Science, Minufiya University, Egypt. \\ ${ }^{2 *}$ Nuclear Materials Authority, P.O. Box 530, El Maadi, Cairo, Egypt. \\ Email: drgehad_m@yahoo.com
}

\begin{abstract}
Lithologically, the rock types of G. El Fereyid - W. Rahaba area are dominantly granites associated with pegmatites. The granitic rocks comprise tonalite and monzogranite with (minor acidic dykes), quartz and pegmatites occur as a vein type (granitic and perthitic pegmatites) hosted within the monzogranite. Structural analysis shows the presence of a prominent set of folds with axes striking WNW to NW and a less prominent set with pronounced ENE and NNW trends. Petrochemical studies and tectonic discrimination diagrams for the monzogranite reveal that it is classified as post orogenic granites (POG). Geochemically, monzogranite shows enrichment (peaks) of large ion lithophile elements (LILE; Pb, $\mathrm{Rb}, \mathrm{Ba}, \mathrm{Sr}$ ) and high field strength elements (HFSE; Y, $\mathrm{Zr}$, $\mathrm{Nd}$,) and depletion (troughs) of K, P and Ti. Pegmatite shows enrichment (peaks) of large ion lithophile elements (LILE; $\mathrm{Pb}, \mathrm{Rb}, \mathrm{Sr}$ ) and high field strength elements (HFSE; Y, Zr, Th, U, Nb) and depletion (troughs) of $\mathrm{K}, \mathrm{P}$ and $\mathrm{Ti}$. They exhibit high $\mathrm{K}$-calc alkaline magma and peraluminous characteristics and considered as post orogenic granites (POG). The monzogranite reveal small to moderate negative Eu anomaly, while the pegmatites reveal moderate to large negative Eu anomaly. The pegmatite displays clear W-type tetrad effect of the REE while, the studied monzogranite do not show tetrad effect.
\end{abstract}

Keywords: Petrology, Geochemistry, G. El Fereyid - W. Rahaba granites, Pegmatites, Egypt.

\section{Introduction}

The investigated area is located in the South Eastern Desert between latitudes $23^{\circ} 15^{\prime} 00^{\prime \prime}-23^{\circ} 30^{\prime} 00^{\prime \prime}$ $\mathrm{N}$ and longitudes $35^{\circ} 15^{\prime} 00^{\prime \prime}-35^{\circ} 30^{\prime} 00^{\prime \prime} \mathrm{E}$. The FCC image of band ratios which covers a major part of study area (Fig.1) is used in regional interpretation for general rock units identification and association. Topographically the area is generally characterized by low to moderate relief, but granitic hills form high peaks of relatively high elevation compared to the surrounding other rock units. Most of the radioactive occurrences in the basement rocks of Egypt are present in the younger granites and associated pegmatites [1]. Many promising criteria including rock compositions, mineralogy, isotopic characteristics and spatial distribution indicate a genetic relationship between granite and the intruding pegmatites [2-4]. These pegmatites have been considered as a favorable uranium and thorium mineralization environments [5].

The high level of radioactivity of these rocks is attributed to the presence of accessory minerals like zircon, monazite, thorite, uranothorite and allanite [6]. The area was studied geologically, structurally, mineralogically, geochemically and radiometrically by numerous authors e.g. [7-10] and [1]. The present study is concerned with detailed geology, petrology and geochemistry of the monzogranite and pegmatites, G. El Fereyid - W. Rahaba, South Eastern Desert, Egypt.

\section{Geologic Setting and Petrography}

The Precambrian basement rocks exposed in G. El Fereyid - W. Rahaba area area represent a part of the Pan-African belt of the Arabian Nubian Shield (Fig. 3). Gneisses represent the oldest rock unit in the mapped area and crop out in the north eastern and south western parts of the area (Fig. 2) and 
highly eroded forming low hills. Ophiolitic mélange forms the oldest rock unit in the studied area with gneisses. Ophiolitic mélange of the study area consists of mixture of blocks and masses of varies dimensions of serpentinites and metagabbros. Metavolcanics crop out in the central part of the area as relatively elongate in shape trending roughly in N-S direction moderately to low relief at G. Urga and G. Um Tineidba areas (Fig. 2).

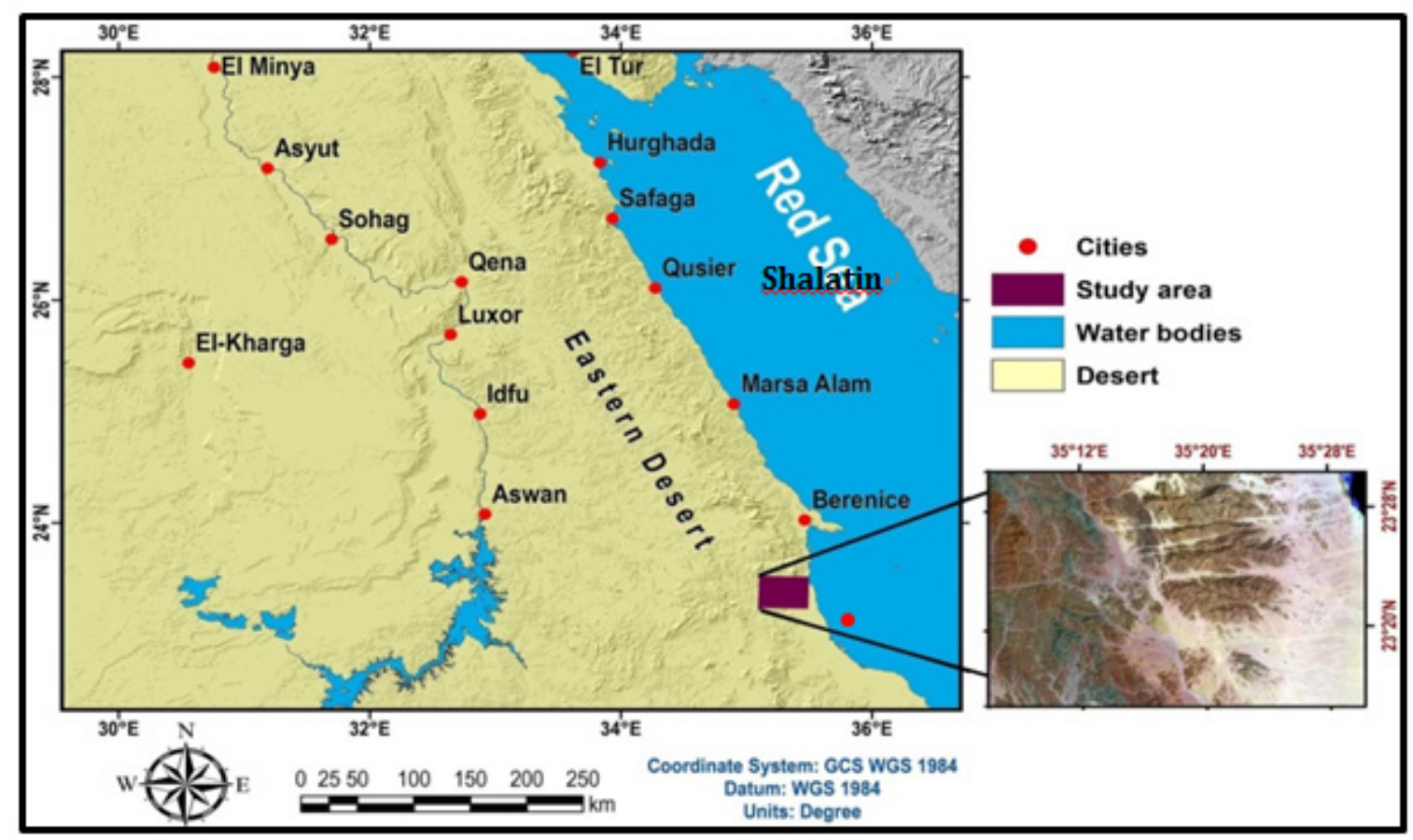

Figure 1. Location map of G. El Fereyid - W. Rahaba area, South Eastern Desert, Egpyt.

Quartz diorite association forms elongated belts of low to moderate relief trending N-S and NNE-SSW at W. Hawdayn and as scattered masses along W. Rahaba (Fig. 2). These rocks are mottled grey to greenish grey, weathered surface; heterogeneous suite with variable grain size and textures. Detailed field mapping of the basement rocks based on the field relations and structure observations, as well as, the petrographical studies revealed that, the area includes older granites (tonalites), younger granites (monzogranite) and pegmatites (Fig. 3). The tonalites are grey in colour, highly exfoliated and forms low hills at the peripheries of the monzogranite. These rocks contain rounded to subrounded xenoliths of diorite and amphibolite up to $30 \mathrm{~cm}$ (Fig. 4a). Monzogranite forms the main granitic masses of G. El Fereyid that is elongated in NW- SE directions (Fig. 4a). Monzogranite are leucocratic, medium to coarse-grained, massive, jointed, exfoliated, pinkish grey in color and highly sheared (Fig. 4b). G. El Fereyid monzogranite pluton is bounded from the west and south by W. Rahaba older granites and from the north by G. Marafai shered granites (Fig. 4c). The monzogranite dissected by a series of fault planes especially in the Western side of the pluton, generally trending NW-SE direction and NE-SW and NW-SE trending basic, acidic dykes and quartz veins (Fig. 4d). Pegmatites occur as pockets and veins that crosscut monzogranite (Fig. 4e). They are very coarse grained, reddish in color. Three different types of pegmatite have been defined based on their mineralogy and morphology. The first type of pegmatite is less abundant and found as an irregular body in the southern part of the area (Fig. 3). This muscovite-rich pegmatite is often very coarse grained and contains large individual crystals of its common constituents. It contains the highest radioelement concentrations compared to other rock units as determined from the in situ gamma ray spectrometric survey. The second type of pegmatite is found in the northwestern part of the mapped area, dissecting the monzogranite and it shows a NW - SE strike with variable dips (Fig. 4f). The third type is in the northern part of the mapped area dissecting the tonalites and striking $\mathrm{E}-\mathrm{W}$. 
Structural analysis shows the presence of a prominent set of folds with axes striking NW to NW and a less prominent set with pronounced ENE and NNW trends. The major and minor faults are mainly thrust, normal and strike slip faults [8]

Tonalite is massive, medium- to coarse-grained, characterized by whitish grey color and porphyritic texture. It consists of plagioclase, K-feldspar and, quartz associated with mafic minerals as hornblende and biotite. Plagioclase is the main feldspar and occurs as anhedral to subhedral tabular crystals of oligoclase $\left(\mathrm{An}_{20}\right)$ characterized by lamellar and pericline twining, occasionally composed with Carlsbad twining. Most of the crystals are partially saussuritized with variable degrees and some crystals are intensively fractured and fragmented forming mortar texture (Fig. 5a). K-feldspar present as anhedral to subhedral crystals of string perthite (Fig. 5b) partially altered to clay minerals. Quartz occurs as anhedral to subhedral crystals, associating the early-crystallized minerals. Mostly, it shows wavy extinction; some crystals are strained and elongated showing undulose extinction and others are cracked and granulated due to the cataclastic effects (Figs. 5c and 5d). Mafic minerals represented by biotite and hornblende. Biotite occurs as subhedral fractured flakes characterized by pale brown color and faint pleochroism from pale brown to pale greenish brown. It is frequently altered to chlorite and iron oxides along its cleavage planes and includes zircon (Fig. 5c). Muscovite is secondary mica mineral occurring as minute flakes after plagioclase (Fig. 5a) or as very fine flakes of variable size commonly associating the reworked quartz grains (Fig. 5d). Hornblende occurs as subhedarl prismatic crystals, which are strongly pleochroic from pale green; green to yellowish green showing simple twinning (Fig. 5e). The common accessories are zircon, titanite, fluroapatite and opaques (Fig. 5f).

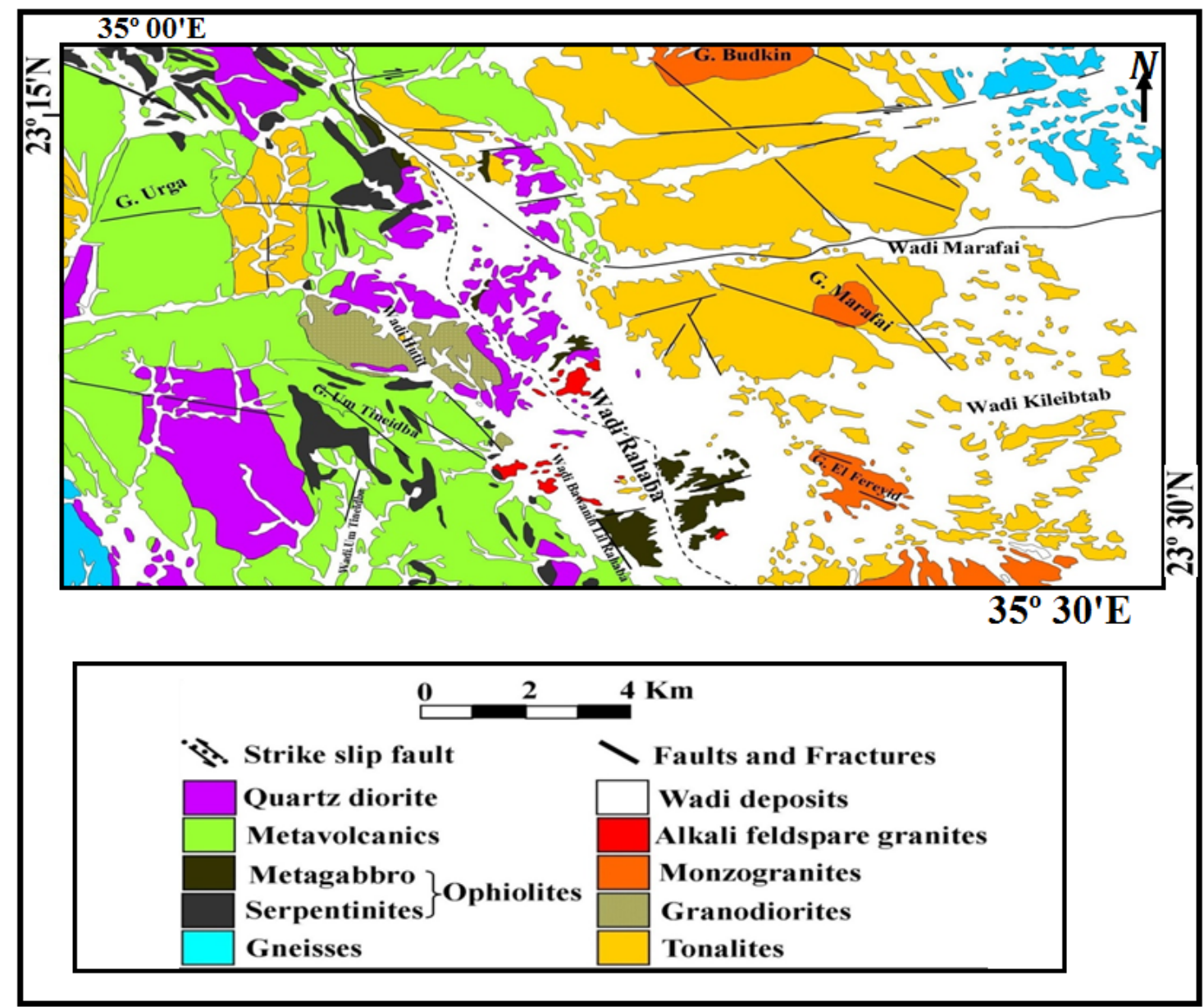

Figure 2. Geologic map of G. El Fereyid - W. Rahaba area, South Eastern Desert, Egypt. 


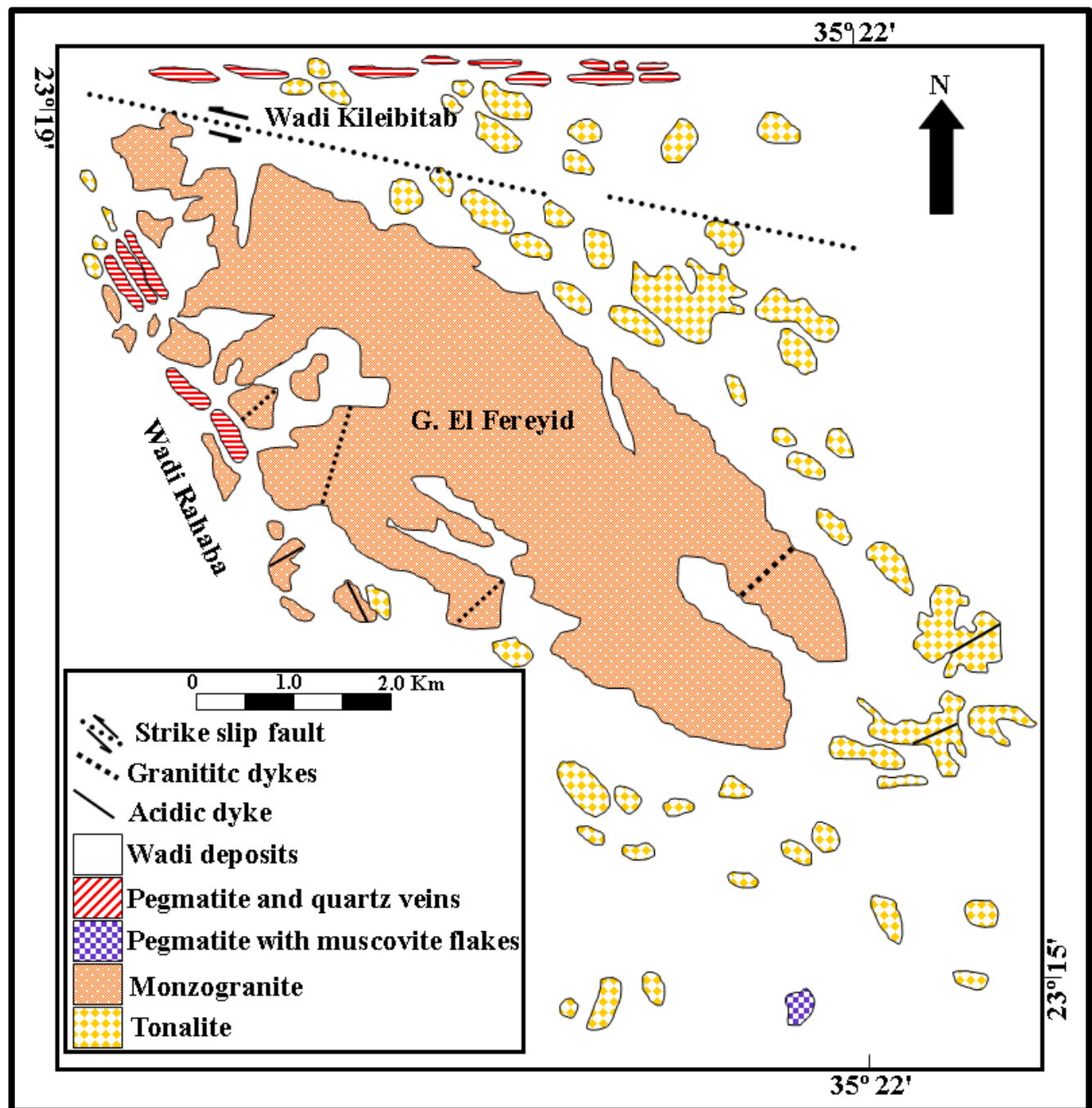

Figure 3. Detailed geologic map of G. El Fereyid - W. Rahaba area, South Eastern Desert, Egypt (Modified after $[1])$.

Monzogranite are mainly medium to coarse-grained granite with grayish pink color and hypidiomorphic texture. Microscopically, it is composed essentially of potash feldspar, plagioclase, quartz as well as the mafic minerals. Potash feldspars found as microcline, microcline perthite, orthoclase-perthite and perthite. Microcline present as euhedral crystals of medium grain size $(3.2 \mathrm{~mm}$ length) exhibiting its characteristic cross-hatched twining (Fig. 6a). Microcline petrthite present as subhedral crystals with coarser grain size (5.2 $\mathrm{mm}$ length) characterized by cross-hatched twining intergrown with net-like perthitic texture (Fig. 6b). Orthoclase perthite present as euhedral prismatic crystals of medium grain size exhibiting its characteristic Carlsbad twining composed with the perthitic texture (Fig. 6c). Plagioclase $\left(\mathrm{An}_{15}\right)$ occurs as subhedral to anhedral prismatic crystals of oligoclase showing albite-pericline (Fig. 6d) and albite-carlsbad twinings (Fig.6e). Some crystals are by myrmeckitic textures where quartz excluded as vermicules and others are fractured and partially microclinized or saussiritized enclosing minute crystal of zircon (Fig. 6f). Quartz occurs as subhedral to anhedral cystals with wavy extinction filling the spaces between the early crystallized minerals (feldspars and mafic). Some crystals are elongated and strained showing moderate undulose extinction (Fig. 6g). Mafic minerals are mainly biotite and hornblende. Biotite is more abundant than hornblende; it occurs as subhedral to anhedral flakes pleochroic from $\mathrm{X}=$ pale brown to $\mathrm{Y}=\mathrm{Z}=$ dark brown. Some flakes are foliated along the fractures and associate the elongated quartz crystals (Fig. 6h) and others are partially altered with variable degrees and transformed to chlorite of penninite type with iron oxyhydroxides excluded along the cleavage planes (Fig. 6i). Hornblende is the second mafic mineral in 
abundance exhibiting its characteristic two-set cleavage in the basal-sectioned crystals. Apatite, epidote, titanite monazite, allanite, and zircon are the main accessory minerals. Titanite occurs as euhedral crystals with sphenoidal form characterized by high relief and high order interference colors (lower fourth order). Monazite occurs as rounded crystal included in biotite and characterized by high relief and high interference colors (upper third order) (Fig. 6j). Zircon occurs as colorless prismatic crystals with high relief; some crystals are surrounded by dark pleochroic haloes within biotite (Fig. 6k).

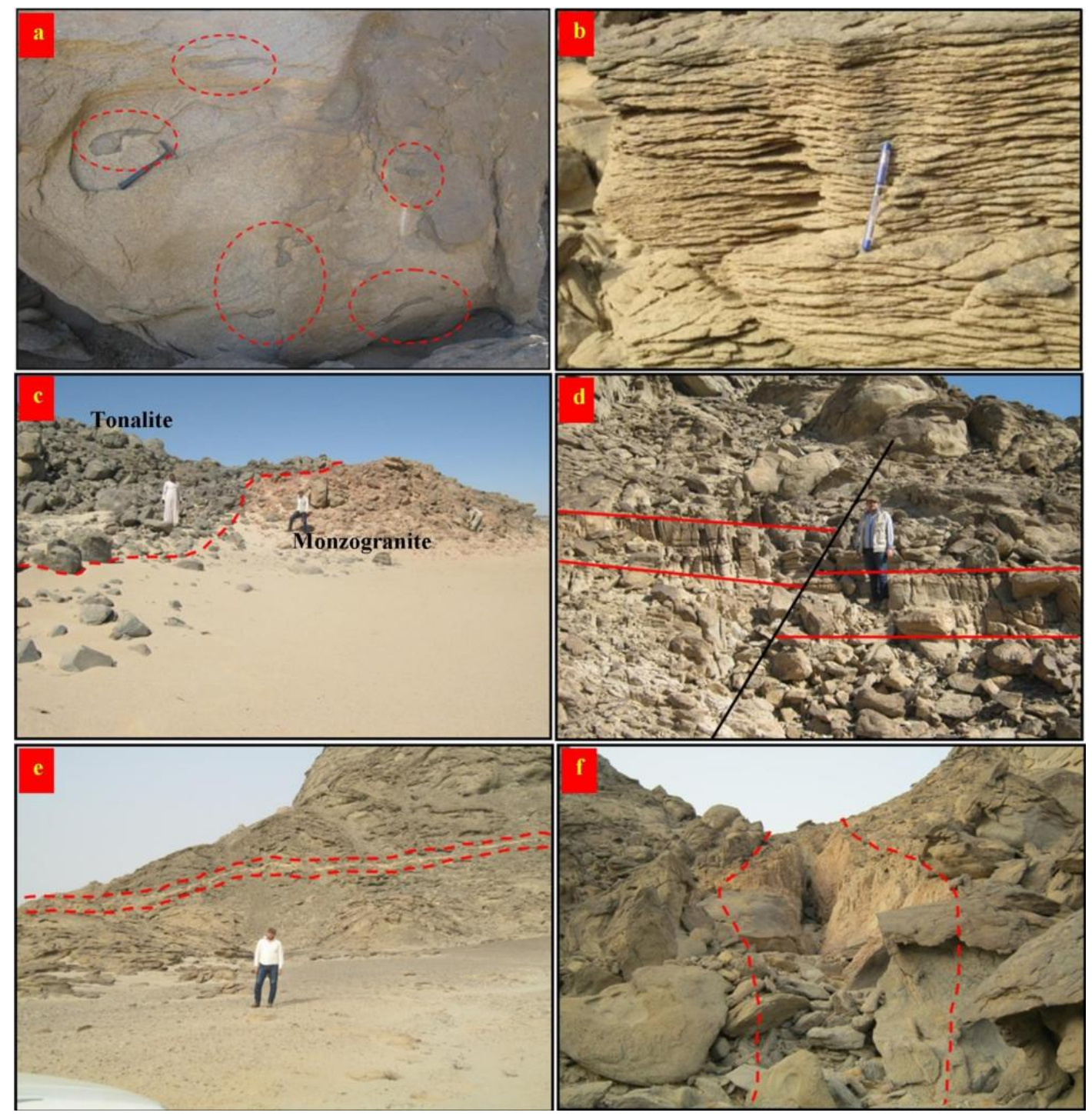

Figure 4. View showing:- a) Xenoliths of diorite present in tonalities, b): Highly sheared monzogranite (Looking E), c): Intrusive contact between monzogranite and tonalites (Looking NW), d): N-S granitic dyke crosscut the monzogranite (Looking N), e): Pegmatite occurs as vein crosscut the monzogranite (Looking N) and f): Pegmatitic veins crosscut the monzogranite of G. El Fereyid - W. Rahaba area, SED, Egypt. (Looking N). 


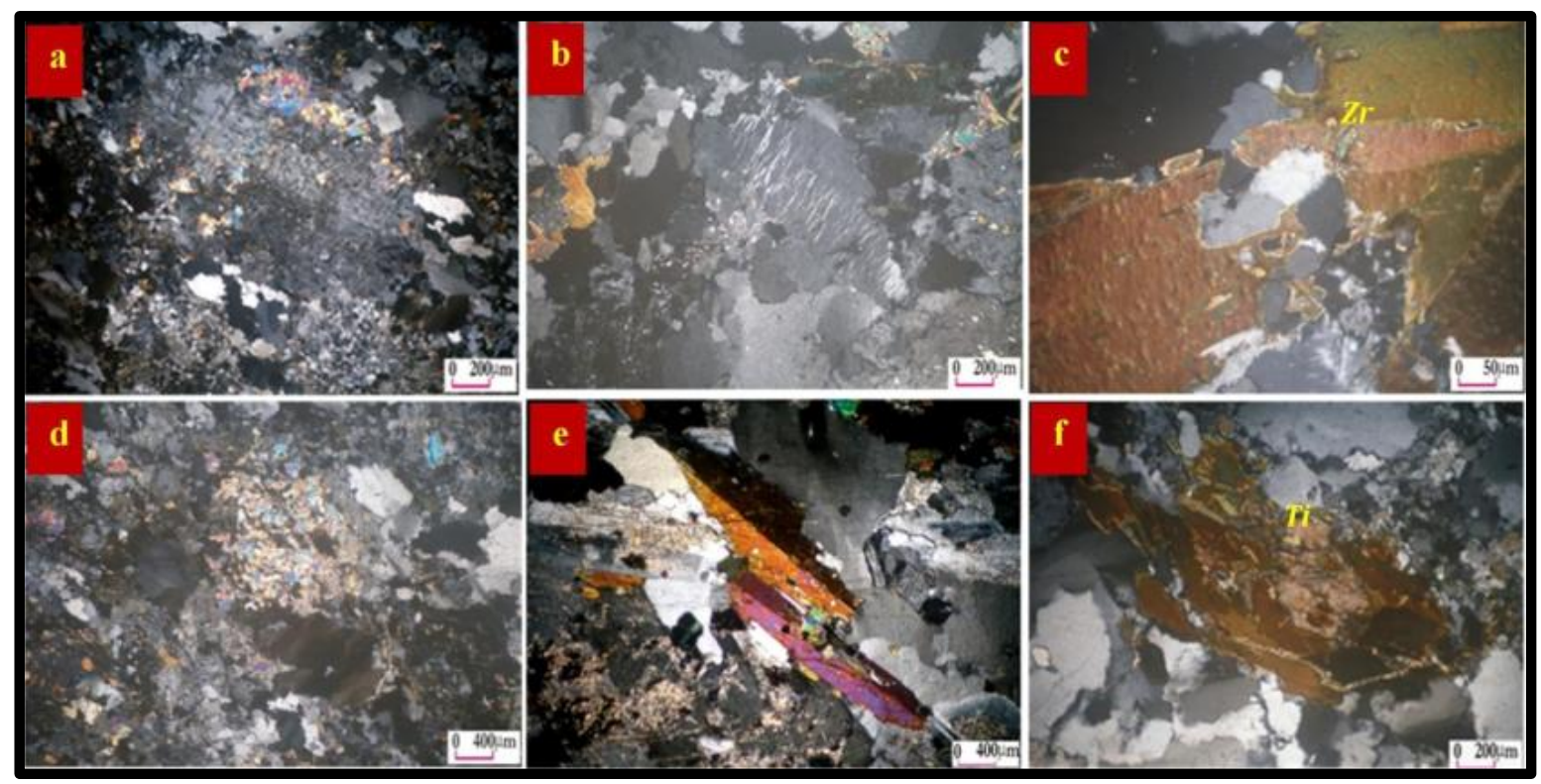

Figure 5. Photomicrographs of tonalite, G. El Fereyid - W. Rahaba area, showing:- a) Crystals of plagioclase showing mortar texture and muscovitization (C. N), b) Crystal of string perthite associated with quartz (C.N), c) Fractured flakes of biotite associated with quartz and enclose crystal of zircon (Zr) (C.N), d) Secondary muscovite associated with reworked quartz (C.N), e) Prismatic crystal of hornblende showing simple twining (C.N) and f) Crystal of titanite (Ti) associated with flakes of biotite (C.N.).

Zircon occurs as colorless prismatic crystals with high relief; some crystals are surrounded by dark pleochroic haloes within biotite (Fig. 6k). Other crystals are characterized by zonation and included in plagioclase. Allanite occurs as elongated euhedral crystal with brown color and masked interference color; fractured by effect of the radioelements (Fig. 6l).

Pegmatite occurs as a vein type (granitic and perthitic pegmatites) hosted within the monzogranite. Granitic pegmatite consists mainly of potash feldspar, quartz, plagioclase, and mafic minerals as pegmatitic crystals with grain size more than $2 \mathrm{~cm}$. Potash feldspar occurs as euhedral to subhedral mega-crystals represented mainly by microcline (Fig. 7a) associated with microcline perthite, flame perthite, and antiperthite. Plagioclase is a minor conistituent occurring as fine crystals included in the megacrysts of potash feldspar (Fig. 7b). It shows pericline- albite twinning and mainly altered to sericite, sometimes, plagioclase in association with quartz crystals shows myrmeckitic texture. Quartz occurs as skeletal crystals digested by the megacrystals of microcline and exhibiting wavy extinction. Biotite occurs as irregular flakes associating plagioclase filling fractures in the potash feldspar (Fig. 7c) or found as euhedral flakes aligned along the fracture in quartz (Fig. 7d). Fergusonite is the main accessory mineral occurring as euhedral prismatic crystals with its pale brown color included in the megacrysts of quartz (Fig. 7e); it is completely isotropic attributed to metamectization due to its radioactive content. Zircon present as fractured crystals coated by iron oxides and associating plagioclase crystals (Fig. 7f). Perthitic pegmatite is composed mainly of megacrysts (more than $2.5 \mathrm{~cm}$ ) of antiperthite (Fig. 8a), microcline (Fig. 8b) and string perthite (Fig. 8c). Perthite crystals are strained characterized by fracturing, undulose extinction and dissected by fractures of secondary silica. Some of the fractures in the microcline megacrysts filled by biotite flakes and iron oxides (see Fig. 8b). Most of the crystals stained by and/or associated with iron oxide, which may be accompanied by amorphous radioactive minerals (Fig. 8c). 


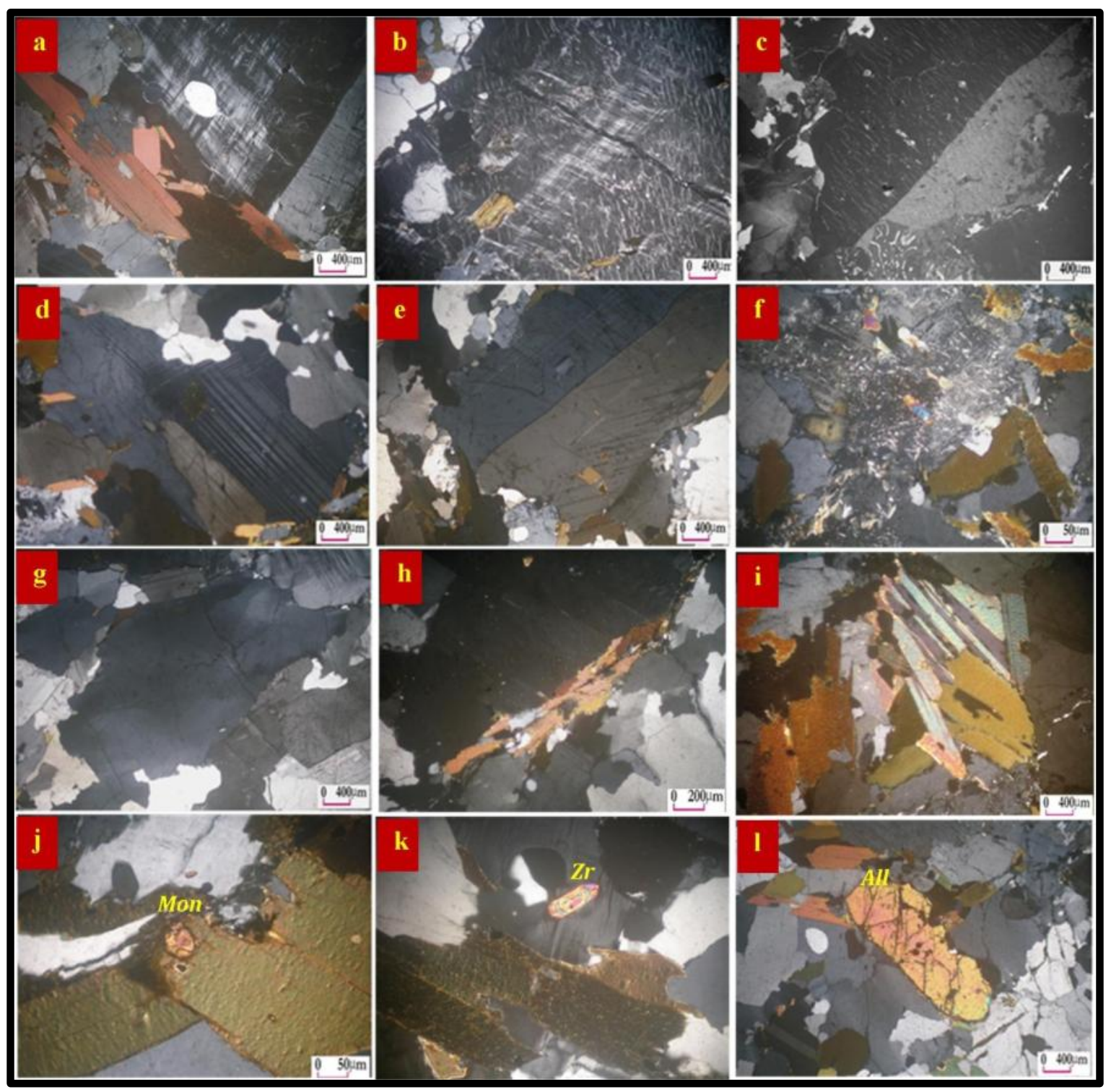

Figure 6. Photomicrographs of monzogranite, G. El Fereyid - W. Rahaba area showing:-a) Euhedral crystal of microcline with cross hatching associating biotite (C.N.), b) Unhedral crystal of net microcline pethite associated with quartz (C.N.), c) Subhedral crystal of orthoclase perthite associated with quartz (C.N.), d) Subhedral crystal of plagioclase with albitic and percline twinings (C.N), e) Subhedral crystal of plagioclase with Carlsbad twining (C.N), f) Partially sussiritized zoned plagioclase enclosing zircon (C.N.), g) Unhedral crystal of quartz showing cracking and undulose extinction (C.N.), h) Stretched flakes of biotite due to compression associated with quartz and plagioclase (C.N.), i) Flakes of biotite partially chloritizted to pennite type of chlorite (C.N.), j) Crystal of monazite (Mon) included in flakes of biotite (C.N.), k) Crystal of zircon with zonation included in plagioclases (C.N.) and l) Crystal of allanite (All) with masked interference color associated with quartz (C.N.). 


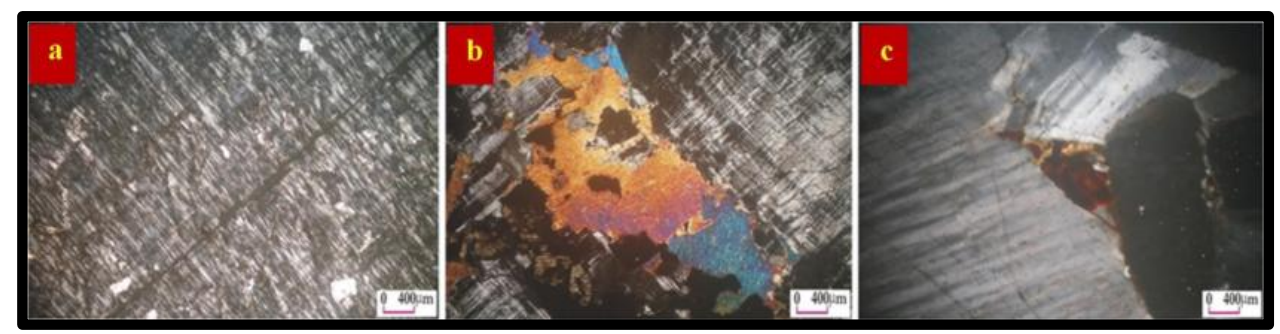

Figure 7. Photomicrographs of perthitic pegmatites, G. El Fereyid - W. Rahaba area showing:- a) Megacryst of antiperthite (C.N), b) Megacryst of microcline enclosing flake of biotite and iton oxides (C.N), c) Secondary iron oxide associated with amorphous radioactive material included in string perthite (C.N).

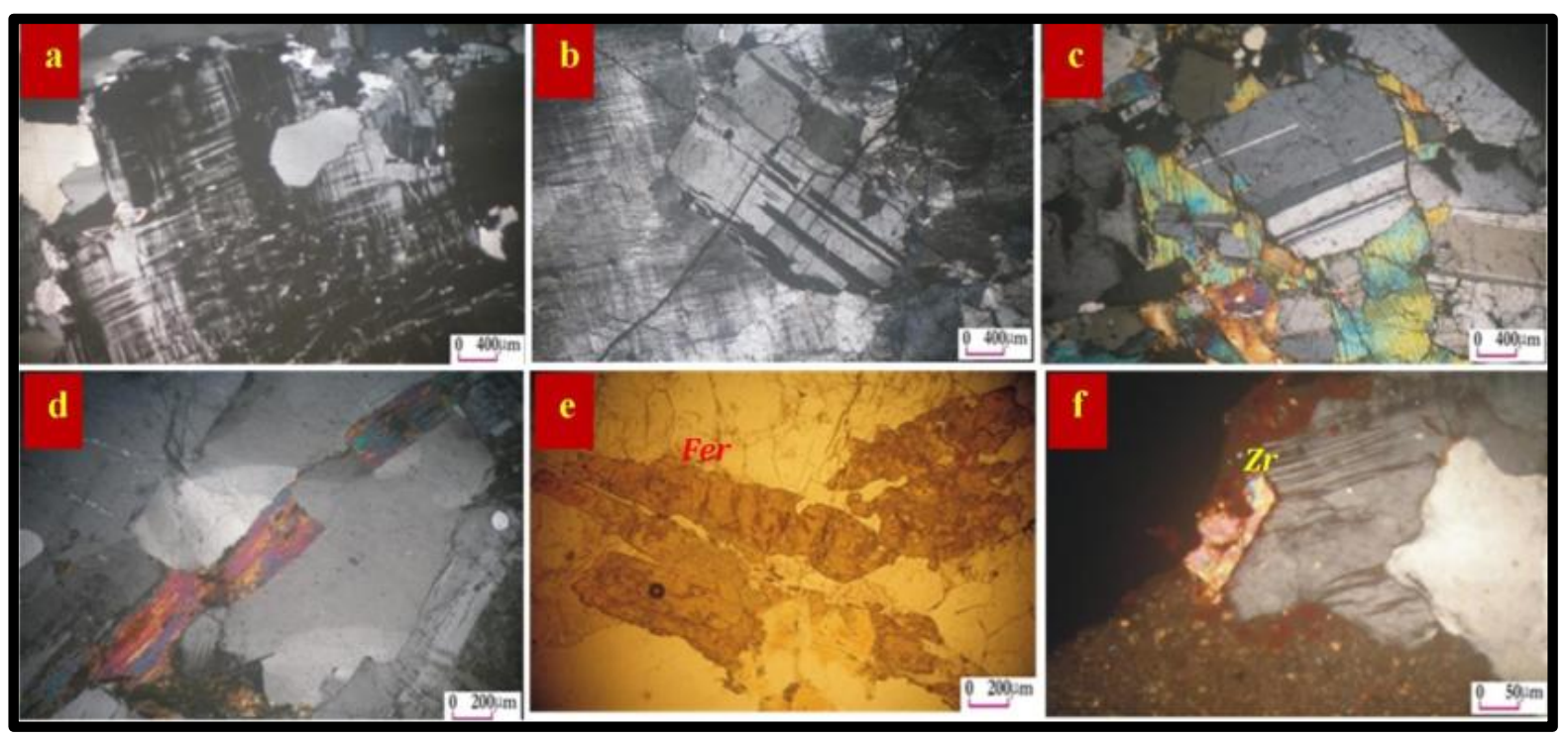

Figure 8. Photomicrographs of granitic pegmatites, G. El Fereyid - W. Rahaba area showing:-a) Megacrystal of microcline enclosing quartz (C.N), b) Crystals of plagioclase included in megacrystal of microcline (C.N), c) Irregular flake of biotite associating albite included in megacrystal of microcline (C.N.), d) Elongated flakes of biotite along the fracture of quartz (C.N.), e) Subhedral crystal of Fergusonite (Fer) associated with quartz of granitic pegmatites (P.P.L) and f) Crystal of zircon (Zr) included in crystal of plagioclase (C.N.).

\section{Geochemistry}

Thirty five (25) samples (Twenty from monzogranite and Fifteen from pegmatites veins) were chemically analyzed and were subjected to petrographic studies. Major oxides, trace elements and rare earth elements were analyzed by ICP-MS in Acme Lab Canada. Data of the major oxides, trace elements and rare earth elements are listed in (Table 1). The geochemistry of the studied area is focused mainly on the monzogranite and the pegmatite of the G. El Fereyid area to clarify their chemical classification, chemical affinity, magma type and tectonic setting.

\subsection{Geochemical Classification}

The classification of the studied monzogranite and pegmatite were chemically confirmed by plotting the analyses on $\mathrm{SiO}_{2}$ versus alkalis diagrams after [11] (Fig. 9a). The studied samples plot in the field of granite. On the basis of R1-R2 discrimination diagram of De La-Roche [12], the studied granites and pegmatite fall in monzogranite field (Fig. 9b). The Ba content is plotted against its K/Rb ratio for pegmatite samples (Fig.9c). All samples of the El Fereyid area show an increase in Ba content with increasing $\mathrm{K} / \mathrm{Rb}$ ratio. The increase in $\mathrm{Ba}$ content is two orders of magnitude for the El Fereyid pegmatite. Therefore, the $\mathrm{Ba}$ content of pegmatitic feldspar is an important indicator of the 
fractionation degree of a pegmatite, as already demonstrated for granitic feldspar by Mehnert and Busch [13]. The Li content is plotted against the $\mathrm{K} / \mathrm{Rb}$ ratio for pegmatite samples (Fig.9d). The majority of the data points fall in the rare-elements class field.

\subsection{Alkaline Affinity}

Maniar and Piccoli [14] used $\left(\mathrm{Al}_{2} \mathrm{O}_{3}\right) /\left(\mathrm{Na}_{2} \mathrm{O}+\mathrm{K}_{2} \mathrm{O}+\mathrm{CaO}\right)$ versus $\left(\mathrm{Al}_{2} \mathrm{O}_{3}\right) /\left(\mathrm{Na}_{2} \mathrm{O}+\mathrm{K}_{2} \mathrm{O}\right)$ to distinguish between peraluminous, metaluminous and peralkaline rocks (Fig. 9e). The figure reveals that the studied rocks fall in peraluminous field except three sample of pegmatites plot in the line between peralkaline and metaluminous fields. Miyashiro (1975) used total alkalis versus SiO2 (wt \%) diagram to distinguish between alkaline and sub-alkaline igneous rocks (Fig. 9f). The figure reveals that the studied samples plot within the subalkaline field. Chappell and White [15] used the bivariate diagram of $\mathrm{Na}_{2} \mathrm{O}$ against $\mathrm{K}_{2} \mathrm{O}$ to differentiate between S-type and I-type granites (Fig. 10a). The figure clears that the studied rocks plot within I-type granite.

\subsection{Tectonic Seeting}

Maniar and Piccoli, [14] published some diagrams to discriminate the tectonic setting of the igneous rocks. On the $\mathrm{SiO}_{2}-\mathrm{Al}_{2} \mathrm{O}_{3}$ diagram the studied rock samples plot within the post-orogenic granite field (POG) (Fig. 10b).

\subsection{Petrogenesis}

The normative Qz-Ab-Or values on the ternary diagrams (Figs. 10c\&d) are used to define the watervapor pressure and the temperature isotherms at which the studied granites were generated. The watervapor pressures up to 3K-bar after [16] and 5 to $10 \mathrm{~K}$-bars after [17]. It is clear that the studied rock samples fall in a relatively $2-5 \mathrm{~K}$-bar and temperature ranging about $760-840^{\circ} \mathrm{C}$ indicating that they were probably formed at moderate levels in the crust. By using the $\mathrm{K} / \mathrm{Rb}$ ratio against $\mathrm{Rb}$ diagram which is useful for comparing samples of different sources (Fig. 10e), this diagram suggests that the crystal fractionation was the most important process during magmatic differentiation. A possible magma source of the studied granitic rocks could be inferred from (Fig. 10f) that shows that, the studied rock samples was formed by partial melting of metagray wackes and partial melting of dacite and tonalite that is found in deeper part of the crust of the Arabian Nubian Shield.

\subsection{Trace Elements}

The concentrations of some trace elements are normalized to a primitive mantle value of Sun and McDonough [18] (Figs. 11a\&b). Monzogranite shows enrichment (peaks) of large ion lithophile elements (LILE; Pb, Rb, Ba, Sr) and high field strength elements (HFSE; Y, Zr, Nd,) and depletion (troughs) of $\mathrm{K}, \mathrm{P}$ and Ti. Pegmatite shows enrichment (peaks) of large ion lithophile elements (LILE; Pb, Rb, Sr) and high field strength elements (HFSE; Y, Zr, Th, U, Nb) and depletion (troughs) of K, P and Ti. The depletion of $\mathrm{Ti}$ is ascribed to fractionation of titanomagnetite.

\subsection{Rare Earth Elements}

Rare earth elements (REEs) analyses of selected samples of monzogranite and pegmatite (Table 1) show total REEs ranging from 154.35 to $240.06 \mathrm{ppm}$ and 41.02 to $244.36 \mathrm{ppm}$ respectively. $\Sigma$ LREEs in monzogranite range from 136.1 to $223.76 \mathrm{ppm}$ with average $173.79 \mathrm{ppm}$, while $\Sigma$ HREEs range from 14.60 to $27.30 \mathrm{ppm}$ with average $20.75 \mathrm{ppm}$. Based on the REE data and according to Cullers and Graf [19] the monzogranite of the studied area reveal moderate negative $\mathrm{Eu}$ anomaly $\left(\mathrm{Eu} / \mathrm{Eu}^{*}=0.38\right.$ to 0.67 ) pattern. It has an average $\mathrm{Eu} / \mathrm{Sm}=0.2$, LREEs/HREEs $=8.79$. The pegmatite reveals high negative Eu anomaly $\left(\mathrm{Eu} / \mathrm{Eu}^{*}=0.12\right.$ to 1.09$)$ pattern. It has an average $\mathrm{Eu} / \mathrm{Sm}=0.077$, LREEs/HREEs $=0.875$. The pattern denotes moderate REEs fractionation and shows a narrow range fractionation of HREEs in both monzogranite and pegmatite. The rare earth elements concentration in pegmatite is less than that of monzogranite due to magmatic fractionation and absence of monazite. Chondrite-normalized REEs 
patterns relative to chondritic values from Boynton,[20], (Figs. 11c\&d), of monzogranite and pegmatite are characterized by strong ( $\Sigma$ LREEs) enrichment and low ( $\Sigma$ HREEs) content due to the presence of some accessory minerals like monazite, apatite, zircon.

\subsection{REE Tetrad Effect}

The term tetrad effect' in geochemistry refers to the subdivision of the 15 lanthanide elements into four groups in a chondrite nor-malized distribution pattern: (1) La - Ce - Pr - Nd, (2) Pm - Sm - Eu - Gd, (3) $\mathrm{Tb}-\mathrm{Dy}-\mathrm{Ho}$, and (4) $\mathrm{Er}-\mathrm{Tm}-\mathrm{Yb}-\mathrm{Lu}$, and each group forms a smooth convex (M-type) or concave (W-type) pattern (Masuda et al., 1987). The chonderite-normalized REE patterns of the pegmatite show W-type tetrad effect similar to that quoted by Masuda et al. [21] (Fig. 11d). The tetrad effect in the studied monzogranite and pegmatite were calculated according to Irber equations [22]:

$\left.\mathrm{Ce}^{*}=\mathrm{Ce}_{\mathrm{N}} / \mathrm{La}_{\mathrm{N}}{ }^{2 / 3} \mathrm{xNd}_{\mathrm{N}}{ }^{1 / 3}\right), \mathrm{Pr}^{*}=\operatorname{Pr}_{\mathrm{N}} /\left(\mathrm{La}_{\mathrm{N}}{ }^{1 / 3} \mathrm{xNd}_{\mathrm{N}}{ }^{2 / 3}\right), \mathrm{Tb}^{*}=\mathrm{Tb}_{\mathrm{N}} /\left(\mathrm{Gd}_{\mathrm{N}}{ }^{2 / 3} \mathrm{xHo}_{\mathrm{N}}{ }^{1 / 3}\right)$, $\mathrm{Dy}^{*}=\mathrm{Dy}_{\mathrm{N}} /\left(\mathrm{Gd}_{\mathrm{N}}{ }^{1 / 3} \mathrm{xHo}_{\mathrm{N}}{ }^{2 / 3}\right), \mathrm{TE}_{3}=\left(\mathrm{Tb}^{*} \mathrm{xDy}\right)^{1 / 2}, \mathrm{TE}_{1}=\left(\mathrm{Ce}^{*} \mathrm{xPr}\right)^{1 / 2}$ and $\mathrm{TE}_{1,3}=\left(\mathrm{TE}_{1} \mathrm{xTE}_{3}\right)^{1 / 2}$

When $\mathrm{TE}_{1,3}$ values are higher than 1.1 , the rock is considered to show the tetrad effect. The studied monzogranite have $\mathrm{TE}_{1,3}$ values less than 1.1, so they do not show tetrad effect (Table 1), while the studied pegmatite has an average $\mathrm{TE}_{1,3}$ of 1.62 , so it show tetrad effect. The fractionation of elements with similar ionic radius and charge is regarded to be sensitive to change in the melt composition during magma differentiation [23-24].

\subsection{Geochemistry of Uranium and Thorium}

The relation between $\mathrm{U}$ ppm and Th ppm may indicate the enrichment or depletion of $\mathrm{U}$ because $\mathrm{Th}$ is chemically stable. The relation between the $\mathrm{U}$ and $\mathrm{Th}$ contents is examined by plotting the $\mathrm{U}$ contents against Th contents (Fig.12). The uranium and thorium show a notable variations with a somewhat increase within each rock type with increasing $\mathrm{SiO}$. The $\mathrm{U} / \mathrm{Th}$ ratio shows irregular variations within each rock type with $\mathrm{SiO}_{2}$ and Th enrichment. A better positive correlation between $\mathrm{U}$ and Th, which may indicate that uranium, is mainly located in thorium rich accessory minerals such as, uranothorite, thorite, zircon, monazite and allanite.

Table 1: Chemical composition of monzogranites and pegmatites from G. El Fereyid - W. Rahaba, South Eastern Desert, Egypt.

\begin{tabular}{l|c|c|c|c|c|c|c|c|c|c|c|c|c|c}
\hline Rock type & \multicolumn{10}{c}{ Monzogranites } \\
\hline S. No. & F1 & F2 & F3 & F5 & F7 & F11 & F15 & F16 & F17 & F18 & F21 & F22 \\
\hline Major oxides \\
\hline $\mathrm{SiO}_{2}$ & $\mathbf{7 2 . 3}$ & $\mathbf{7 2 . 7 2}$ & $\mathbf{7 1 . 1 6}$ & $\mathbf{7 0 . 8 8}$ & $\mathbf{7 2 . 7 8}$ & $\mathbf{7 2 . 2 4}$ & $\mathbf{7 0 . 9 8}$ & $\mathbf{7 0 . 3 5}$ & $\mathbf{7 1 . 7}$ & $\mathbf{7 1 . 4}$ & $\mathbf{7 0 . 7 9}$ & $\mathbf{7 1 . 2 9}$ \\
\hline $\mathrm{TiO}_{2}$ & 0.52 & 0.12 & 0.38 & 0.4 & 0.11 & 0.43 & 0.44 & 0.43 & 0.13 & 0.63 & 0.93 & $0 . .37$ \\
\hline $\mathrm{Al}_{2} \mathrm{O}_{3}$ & 14.28 & 14.8 & 15.14 & 15.61 & 14.41 & 14.42 & 15.38 & 14.92 & 13.9 & 15.02 & 14.92 & 14.38 \\
\hline $\mathrm{Fe}_{2} \mathrm{O}_{3}{ }^{*}$ & 2.96 & 1.7 & 2.44 & 2.45 & 1.55 & 2.17 & 2.15 & 3.17 & 3.65 & 3.02 & 2.35 & 2.87 \\
\hline $\mathrm{MnO}$ & 0.07 & 0.018 & 0.031 & 0.034 & 0.018 & 0.061 & 0.065 & 0.059 & 0.057 & 0.031 & 0.064 & 0.019 \\
\hline $\mathrm{MgO}$ & 0.93 & 0.3 & 0.63 & 0.66 & 0.28 & 0.8 & 0.75 & 0.81 & 0.71 & 0.55 & 0.8 & 0.65 \\
\hline $\mathrm{CaO}$ & 1.02 & 1 & 1.22 & 1.3 & 1.4 & 0.9 & 1.16 & 1.45 & 1.42 & 1.24 & 1.41 & 1.4 \\
\hline $\mathrm{Na} 2 \mathrm{O}$ & 4.32 & 4.1 & 3.82 & 3.8 & 4.2 & 4.33 & 4.04 & 4.47 & 3.99 & 3.9 & 4.16 & 3.77 \\
\hline $\mathrm{K}_{2} \mathrm{O}$ & 3.99 & 4.71 & 4.5 & 4.41 & 4.75 & 4.08 & 4.38 & 3.76 & 4.56 & 3.99 & 4.51 & 4.66 \\
\hline $\mathrm{P}_{2} \mathrm{O}_{5}$ & 0.27 & 0.02 & 0.08 & 0.11 & 0.1 & 0.23 & 0.21 & 0.24 & 0.14 & 0.03 & 0.15 & 0.16 \\
\hline $\mathrm{L} . \mathrm{O} . \mathrm{I}$ & 0.33 & 0.51 & 0.4 & 0.35 & 0.3 & 0.34 & 0.35 & 0.34 & 0.36 & 0.3 & 0.46 & 0.32 \\
\hline $\mathrm{Total}$ & 100.99 & 99.99 & 99.80 & 100.00 & 100.00 & 100.00 & 99.90 & 99.99 & 100.62 & 100.1 & 100.54 & 99.89 \\
\hline $\mathrm{CIPW}$ norm3 & & & & & & & & \\
\hline $\mathrm{Qz}$ & $\mathbf{2 9 . 0 9}$ & $\mathbf{2 8 . 3 1}$ & $\mathbf{2 8 . 3 9}$ & $\mathbf{2 8 . 9 4}$ & $\mathbf{2 7 . 0 7}$ & 28.97 & 27.71 & 26.32 & $\mathbf{2 7 . 3 3}$ & 30.05 & 25.54 & 28.01 \\
\hline $\mathrm{Or}$ & 23.58 & 27.83 & 26.59 & 26.06 & 28.07 & 24.11 & 25.88 & 22.22 & 26.95 & 23.58 & 26.65 & 27.54 \\
\hline $\mathrm{Ab}$ & 36.55 & 34.69 & 32.32 & 32.15 & 35.54 & 36.64 & 34.19 & 37.82 & 33.76 & 33 & 35.2 & 31.9 \\
\hline $\mathrm{An}$ & 3.3 & 4.83 & 5.53 & 5.33 & 6.29 & 2.96 & 4.38 & 5.63 & 6.13 & 596 & 6.02 & 5.9 \\
\hline
\end{tabular}




\begin{tabular}{|c|c|c|c|c|c|c|c|c|c|c|c|c|}
\hline $\mathrm{C}$ & 1.65 & 1.19 & 1.96 & 2.16 & 0.05 & 2.79 & 2.39 & 1.43 & 0.15 & 2.1 & 0.99 & 0.97 \\
\hline Di/ Wo & 0 & 0 & 0 & 0 & 0 & 0 & 0 & 0 & 0 & 0 & 0 & 0 \\
\hline Di /en & 0 & 0 & 0 & 0 & 0 & 0 & 0 & 0 & 0 & 0 & 0 & 0 \\
\hline Hy & 2.32 & 0.75 & 1.57 & 1.57 & 0.64 & 1.99 & 1.87 & 2.02 & 1.77 & 1.37 & 1.99 & 1.62 \\
\hline $\mathrm{Ilm}$ & 0.15 & 0.04 & 0.07 & 0.07 & 0.04 & 0.13 & 0.14 & 0.13 & 0.12 & 0.07 & 0.14 & 0.04 \\
\hline Hem & 2.96 & 1.7 & 2.44 & 2.44 & 1.55 & 2.7 & 2.15 & 3.170 & 3.65 & 3.02 & 2.35 & 2.87 \\
\hline $\mathrm{Ac}$ & 0 & 0 & 0 & 0 & 0 & 0 & 0 & 0 & 0 & 0 & 0 & 0 \\
\hline Ap & 0 & 0.05 & 0.19 & 0.25 & 0.23 & 0.53 & 0.49 & 0.56 & 0.32 & 0.07 & 0.35 & 0.37 \\
\hline $\operatorname{Tn}$ & 0 & 0 & 0 & 0 & 0 & 0 & 0 & 0 & 0.16 & 0 & 0 & 0 \\
\hline $\mathrm{Mt}$ & 0 & 0 & 0 & 0 & 0 & 0 & 0 & 0 & 0 & 0 & 0 & 0 \\
\hline \multicolumn{13}{|c|}{ Trace elements (ppm) } \\
\hline $\mathrm{U}$ & 4.1 & 5.7 & 3.7 & 2.9 & 4.8 & 2.2 & 2.1 & 2.5 & 5.1 & 3.3 & 2.7 & 4.9 \\
\hline Th & 16.3 & 29.1 & 25.6 & 24.6 & 29 & 11.7 & 9.8 & 13 & 28.6 & 28.7 & 20.6 & 22.3 \\
\hline $\mathrm{Cr}$ & 228 & 195 & 220 & 162 & 180 & 202 & 190 & 193 & 261 & 195 & 115 & 260 \\
\hline $\mathrm{Y}$ & 22.8 & 30.2 & 20.8 & 40.9 & 33.6 & 23.7 & 23.4 & 21.1 & 46 & 44.5 & 46.1 & 37.5 \\
\hline $\mathrm{Nb}$ & 12.67 & 14.56 & 12.2 & 9.9 & 8.95 & 9.11 & 8.7 & 7.95 & 13.56 & 11.89 & 16.3 & 11.3 \\
\hline $\mathrm{Zr}$ & 49.8 & 40.8 & 45.5 & 39.8 & 41.2 & 41.5 & 37.1 & 46 & 43.6 & 48.9 & 35.2 & 35.6 \\
\hline $\mathrm{Ni}$ & 125.6 & 120.3 & 90.8 & 88.9 & 144.4 & 124.5 & 113.5 & 111.7 & 114.5 & 88.9 & 63.7 & 92.6 \\
\hline $\mathrm{Ba}$ & 922 & 865 & 980 & 695 & 699 & 861 & 986 & 814 & 789 & 988 & 833 & 955 \\
\hline $\mathrm{Pb}$ & 41.98 & 54.6 & 44.6 & 70.2 & 66.9 & 39.73 & 60.78 & 50.91 & 38.9 & 50.19 & 148.24 & 65.36 \\
\hline $\mathrm{Rb}$ & 103.6 & 90.5 & 120.6 & 130.5 & 96.5 & 85.8 & 98.5 & 90.4 & 95.8 & 88.3 & 131.7 & 111.1 \\
\hline $\mathrm{Sr}$ & 282 & 250 & 280 & 285 & 274 & 278 & 276 & 287 & 266 & 260 & 239 & 275 \\
\hline $\mathrm{Zn}$ & 381.8 & 800.5 & 655.2 & 579.8 & 578.9 & 426.1 & 847.8 & 559.8 & 933.6 & 908.7 & 2267.7 & 789.9 \\
\hline $\mathrm{Ti}$ & 0.58 & 0.56 & 0.57 & 0.55 & 0.72 & 0.47 & 0.56 & 0.52 & 0.44 & 0.72 & 0.74 & 0.54 \\
\hline $\mathrm{Cu}$ & 543.7 & 889.6 & 879.5 & 2255.6 & 807.3 & 708.2 & 1448.3 & 962.8 & 708.6 & 908 & 3835.6 & 908.6 \\
\hline $\mathrm{V}$ & 43 & 40 & 31 & 38 & 30 & 32 & 33 & 32 & 30 & 32 & 31 & 32 \\
\hline $\mathrm{Cs}$ & 1.7 & 0.8 & 0.6 & 1.3 & 1.2 & 0.8 & 1.2 & 1.2 & 1.3 & 1.4 & 3.6 & 1.5 \\
\hline $\mathrm{Be}$ & 2 & 2 & 2 & 2 & 3 & 2 & 2 & 2 & 2 & 4 & 2 & 3 \\
\hline $\mathrm{Sn}$ & 11.2 & 14.6 & 40.2 & 30.8 & 51.3 & 11.6 & 21.6 & 15 & 30.5 & 16.8 & 52.6 & 32.3 \\
\hline $\mathrm{Li}$ & 35.4 & 23.3 & 29.6 & 33.6 & 27.9 & 20 & 24.1 & 22.4 & 26.1 & 28.9 & 34.5 & 25.6 \\
\hline $\mathrm{Ta}$ & 1.1 & 0.7 & 0.6 & 0.7 & 0.6 & 0.7 & 0.7 & 0.6 & 0.8 & 1.6 & 1.4 & 0.6 \\
\hline Co & 10.2 & 7.5 & 5.5 & 10.1 & 6.7 & 8.5 & 8.5 & 8.1 & 8.6 & 8.5 & 6.9 & 7.9 \\
\hline $\mathrm{Hf}$ & 1.37 & 1.35 & 2.3 & 2.9 & 1.9 & 1.21 & 1.08 & 1.21 & 2.55 & 2.35 & 1.14 & 2.06 \\
\hline $\mathrm{Ga}$ & 21.26 & 20.12 & 21.5 & 20.14 & 19.87 & 20.15 & 20.52 & 19.87 & 19.88 & 20.82 & 21.03 & 21.11 \\
\hline \multicolumn{13}{|c|}{ Rare earth elements (ppm) } \\
\hline $\mathrm{La}$ & 43.60 & 28.40 & 47.90 & 36.20 & 53.10 & 29.90 & 35.00 & 36.00 & 46.80 & 30.40 & 40.60 & 50.10 \\
\hline $\mathrm{Ce}$ & 93.10 & 62.50 & 101.50 & 102.20 & 92.20 & 64.65 & 72.07 & 75.38 & 100.30 & 70.20 & 83.22 & 80.70 \\
\hline $\operatorname{Pr}$ & 11.40 & 7.50 & 11.70 & 10.20 & 11.20 & 7.90 & 8.50 & 9.30 & 11.50 & 11.20 & 10.20 & 9.60 \\
\hline $\mathrm{Nd}$ & 39.10 & 30.60 & 44.50 & 45.50 & 38.90 & 28.20 & 30.40 & 32.70 & 38.80 & 30.50 & 34.90 & 29.90 \\
\hline $\mathrm{Sm}$ & 6.80 & 6.20 & 6.70 & 6.60 & 6.70 & 5.60 & 5.80 & 5.90 & 7.20 & 5.60 & 7.00 & 6.80 \\
\hline $\mathrm{Eu}$ & 1.20 & 0.90 & 1.00 & 1.00 & 1.20 & 1.10 & 1.20 & 1.10 & 0.90 & 1.10 & 1.00 & 0.80 \\
\hline Gd & 5.50 & 4.90 & 6.10 & 5.10 & 5.80 & 4.90 & 5.80 & 4.40 & 5.60 & 5.20 & 6.20 & 6.10 \\
\hline $\mathrm{Tb}$ & 1.00 & 0.80 & 0.90 & 0.70 & 0.80 & 0.90 & 0.90 & 0.80 & 0.90 & 1.00 & 1.20 & 0.70 \\
\hline Dy & 4.10 & 5.50 & 5.70 & 4.00 & 4.00 & 4.60 & 4.20 & 3.90 & 6.60 & 5.60 & 6.70 & 4.50 \\
\hline Но & 1.00 & 1.30 & 1.40 & 0.90 & 0.90 & 0.90 & 0.90 & 0.80 & 1.50 & 1.30 & 1.60 & 1.00 \\
\hline Er & 2.70 & 4.10 & 4.00 & 2.00 & 2.70 & 2.40 & 2.60 & 2.10 & 4.70 & 4.50 & 4.80 & 2.80 \\
\hline $\mathrm{Yb}$ & 2.80 & 4.70 & 4.90 & 2.00 & 2.70 & 2.5 & 2.30 & 2.00 & 5.1 & 4.60 & 5.2 & 2.20 \\
\hline $\mathrm{Lu}$ & 0.5 & 0.7 & 0.8 & 0.3 & 0.4 & 0.4 & 0.4 & 0.3 & 0.8 & 0.8 & 0.8 & 0.3 \\
\hline $\mathrm{Tm}$ & 0.4 & 0.7 & 0.7 & 0.4 & 0.4 & 0.4 & 0.4 & 0.3 & 0.8 & 0.7 & 0.8 & 0.4 \\
\hline
\end{tabular}




\begin{tabular}{|c|c|c|c|c|c|c|c|c|c|c|c|c|}
\hline $\mathrm{Zr} / \mathrm{Hf}$ & 36.4 & 30.2 & 19.8 & 13.7 & 21.7 & 34.3 & 34.4 & 38.0 & 17.1 & 20.8 & 30.9 & 17.3 \\
\hline $\mathrm{Zr} / \mathrm{Sr}$ & 0.2 & 0.2 & 0.2 & 0.1 & 0.2 & 0.1 & 0.1 & 0.2 & 0.2 & 0.2 & 0.1 & 0.1 \\
\hline $\mathrm{Rb} / \mathrm{Zr}$ & 2.1 & 2.2 & 2.7 & 3.3 & 2.3 & 2.1 & 2.7 & 2.0 & 2.2 & 1.8 & 3.7 & 3.1 \\
\hline $\mathrm{Rb} / \mathrm{Sr}$ & 0.4 & 0.4 & 0.4 & 0.5 & 0.4 & 0.3 & 0.4 & 0.3 & 0.4 & 0.3 & 0.6 & 0.4 \\
\hline $\mathrm{Sr} / \mathrm{Rb}$ & 2.7 & 2.8 & 2.3 & 2.2 & 2.8 & 3.2 & 2.8 & 3.2 & 2.8 & 2.9 & 1.8 & 2.5 \\
\hline $\mathrm{Y} / \mathrm{Nb}$ & 1.8 & 2.1 & 1.7 & 4.1 & 3.8 & 2.6 & 2.7 & 2.7 & 3.4 & 3.7 & 2.8 & 3.1 \\
\hline $\mathrm{Nb} / \mathrm{Ta}$ & 11.5 & 20.80 & 20.30 & 14.1 & 14.9 & 13.0 & 12.4 & 13.30 & 17.0 & 7.4 & 11.6 & 18.80 \\
\hline $\mathrm{Yb} / \mathrm{Ta}$ & 2.5 & 6.7 & 8.2 & 2.9 & 4.5 & 3.6 & 3.3 & 3.3 & 6.6 & 4.5 & 3.7 & 3.7 \\
\hline $\mathrm{Ba} / \mathrm{Rb}$ & 8.9 & 9.6 & 8.1 & 5.3 & 7.2 & 10.0 & 10.0 & 9.0 & 8.2 & 11.2 & 6.3 & 8.6 \\
\hline $\mathrm{Eu} / \mathrm{Sm}$ & 0.2 & 0.1 & 0.1 & 0.2 & 0.2 & 0.2 & 0.2 & 0.2 & 0.1 & 0.2 & 0.1 & 0.1 \\
\hline $\mathrm{K} / \mathrm{Rb}$ & 319.7 & 432.0 & 309.8 & 280.5 & 408.6 & 394.7 & 369.1 & 345.3 & 395.1 & 375.1 & 284.3 & 348.2 \\
\hline $\mathrm{Rb} / \mathrm{Ba}$ & 0.1 & 0.1 & 0.1 & 0.2 & 0.1 & 0.1 & 0.1 & 0.1 & 0.1 & 0.1 & 0.2 & 0.1 \\
\hline $\mathrm{K} / \mathrm{Ba}$ & 35.9 & 45.2 & 38.1 & 52.7 & 56.4 & 39.3 & 36.9 & 38.333 & 48.0 & 33.5 & 44.9 & 40.5 \\
\hline$\sum$ REEs & 213.20 & 158.80 & 237.80 & 217.00 & 221.00 & 154.35 & 170.47 & 174.98 & 231.80 & 172.7 & 204.22 & 195.90 \\
\hline$\sum$ LREEs & 195.20 & 136.10 & 213.30 & 201.70 & 203.30 & 137.35 & 152.97 & 160.38 & 205.50 & 149.0 & 176.92 & 177.90 \\
\hline$\sum$ HREEs & 18.0 & 22.70 & 24.50 & 15.30 & 17.70 & 17.0 & 17.50 & 14.60 & 26.30 & 23.70 & 27.30 & 18.0 \\
\hline $\begin{array}{l}\sum \text { LREEs } \\
/ \sum \text { HREEs }\end{array}$ & 10.84 & 6.0 & 8.71 & 13.18 & $11 . .49$ & 8.08 & 8.74 & 10.98 & 7.81 & 6.29 & 6.48 & 9.88 \\
\hline $\mathrm{Eu} / \mathrm{Eu}^{*}$ & 0.60 & 0.50 & 0.48 & 0.53 & 0.59 & 0.64 & 0.63 & 0.67 & 0.43 & 0.62 & 0.46 & 0.38 \\
\hline$(\mathrm{La} / \mathrm{Sm})_{\mathrm{n}}$ & 4.03 & 2.88 & 4.50 & 3.45 & 4.99 & 3.36 & 3.80 & 3.84 & 4.09 & 3.41 & 3.65 & 4.63 \\
\hline$(\mathrm{La} / \mathrm{Yb})_{\mathrm{n}}$ & 10.50 & 4.07 & 6.59 & 12.20 & 13.26 & 8.06 & 10.26 & 12.14 & 5.95 & 4.46 & 5.26 & 15.35 \\
\hline$(\mathrm{Ce} / \mathrm{Yb})_{\mathrm{n}}$ & 8.60 & 3.44 & 5.36 & 13.22 & 8.83 & 6.69 & 8.11 & 9.75 & 4.90 & 3.95 & 4.14 & 9.49 \\
\hline$(\mathrm{Eu} / \mathrm{Yb})_{\mathrm{n}}$ & 1.22 & 0.54 & 0.58 & 1.42 & 1.26 & 1.25 & 1.48 & 1.56 & 0.48 & 0.68 & 0.55 & 1.03 \\
\hline$(\mathrm{Tb} / \mathrm{Yb})_{\mathrm{n}}$ & 1.60 & 0.8 & 0.8 & 1.50 & 1.3 & 1.6 & 1.7 & 1.8 & 0.7 & 1.0 & 1.0 & 1.4 \\
\hline $\mathrm{TE}_{1}$ & 1.08 & 1.01 & 1.03 & 1.09 & 0.97 & 1.07 & 1.04 & 1.06 & 1.09 & 1.26 & 1.06 & 0.99 \\
\hline $\mathrm{TE}_{3}$ & 0.95 & 0.92 & 0.86 & 0.86 & 0.86 & 1.07 & 0.94 & 1.04 & 0.90 & 1.0 & 0.99 & 0.79 \\
\hline $\mathrm{TE}_{1.3}$ & 1.02 & 0.96 & 0.94 & 0.97 & 0.92 & 1.07 & 0.99 & 1.05 & 0.99 & 1.13 & 1.03 & 0.89 \\
\hline
\end{tabular}

Table 1 (Continued)

\begin{tabular}{|c|c|c|c|c|c|c|c|c|c|c|c|c|}
\hline \multirow{2}{*}{$\begin{array}{l}\text { Rock type } \\
\text { S. No. }\end{array}$} & \multicolumn{8}{|c|}{ Monzogranites } & \multicolumn{4}{|c|}{ Pegmatites veins } \\
\hline & $\mathrm{F} 23$ & $\mathrm{~F} 24$ & F25 & $\mathrm{F} 26$ & F30 & F33 & F35 & F36 & $\mathrm{B} 2$ & B3 & B5 & B9 \\
\hline \multicolumn{13}{|c|}{ Major oxides } \\
\hline $\mathrm{SiO}_{2}$ & 71.09 & 72.2 & 70.4 & 72.09 & 73.6 & 72.32 & 72.36 & 71.81 & 77.01 & 73.89 & 76.18 & 74.82 \\
\hline $\mathrm{TiO}_{2}$ & 0.39 & 0.55 & 0.42 & 0.18 & 0.11 & 0.41 & 0.42 & 0.28 & 0.06 & 0.04 & 0.19 & 0.17 \\
\hline $\mathrm{Al}_{2} \mathrm{O}_{3}$ & 14.21 & 14.04 & 15.1 & 15.33 & 14.4 & 14.39 & 14.59 & 15.11 & 10.6 & 12.95 & 11.36 & 12.36 \\
\hline $\mathrm{Fe}_{2} \mathrm{O}_{3}$ * & 2.88 & 2.66 & 2.44 & 1.8 & 1.5 & 2.16 & 2.07 & 2.12 & 1.57 & 2.33 & 2.46 & 1.9 \\
\hline $\mathrm{MnO}$ & 0.035 & 0.062 & 0.023 & 0.016 & 0.016 & 0.052 & 0.058 & 0.021 & 0.02 & 0.02 & 0.05 & 0.04 \\
\hline $\mathrm{MgO}$ & 0.82 & 0.91 & 0.82 & 0.42 & 0.28 & 0.76 & 0.7 & 0.55 & 0.15 & 0.15 & 0.45 & 0.43 \\
\hline $\mathrm{CaO}$ & 1.27 & 1.06 & 1.44 & 1.05 & 1.4 & 1.15 & 1.27 & 1.1 & 0.34 & 0.22 & 0.13 & 0.18 \\
\hline $\mathrm{Na}_{2} \mathrm{O}$ & 4.05 & 4.13 & 4.22 & 4.00 & 4.2 & 3.62 & 4.57 & 3.9 & 3.99 & 4.77 & 3.7 & 4.03 \\
\hline $\mathrm{K}_{2} \mathrm{O}$ & 4.33 & 3.87 & 3.89 & 4.71 & 4.75 & 4.44 & 3.32 & 4.66 & 3.6 & 3.86 & 4.43 & 4.55 \\
\hline $\mathrm{P}_{2} \mathrm{O}_{5}$ & 0.06 & 0.19 & 0.14 & 0.04 & 0.02 & 0.18 & 0.24 & 0.12 & 0.01 & 0.01 & 0.04 & 0.04 \\
\hline L.O.I & 0.36 & 0.33 & 0.41 & 0.36 & 0.4 & 0.32 & 0.4 & 0.33 & 1.65 & 1.49 & 0.81 & 1.08 \\
\hline Total & 99.50 & 100.00 & 99.28 & 99.99 & 100.67 & 99.80 & 99.99 & 100.00 & 99.00 & 99.73 & 99.80 & 99.60 \\
\hline \multicolumn{13}{|c|}{ CIPW norm3 } \\
\hline $\mathrm{Qz}$ & 27.1 & 30.27 & 28.39 & 28.03 & 27.72 & 31.18 & 29.98 & 28.43 & 39.37 & 28.8 & 36.87 & 33.05 \\
\hline Or & 26.24 & 22.87 & 22.99 & 27.83 & 28.07 & 26.24 & 19.62 & 27.54 & 21.27 & 28.72 & 26.18 & 26.89 \\
\hline $\mathrm{Ab}$ & 34.27 & 34.95 & 33.76 & 33.85 & 35.54 & 30.63 & 38.67 & 33 & 33.76 & 37.57 & 31.31 & 34.1 \\
\hline An & 5.12 & 4.02 & 6.23 & 4.95 & 6.41 & 4.53 & 4.73 & 4.72 & 0.38 & 1.03 & 0.38 & 0.63 \\
\hline $\mathrm{C}$ & 0.77 & 1.58 & 2.04 & 1.84 & 0 & 1.97 & 1.74 & 1.92 & 0 & 0.01 & 0.34 & 0.57 \\
\hline
\end{tabular}




\begin{tabular}{c|c|c|c|c|c|c|c|c|c|c|c|c}
\hline $\mathrm{Di} / \mathrm{Wo}$ & 0 & 0 & 0 & 0 & 0.24 & 0 & 0 & 0 & 0.03 & 0 & 0 & 0 \\
\hline $\mathrm{Di} / \mathrm{en}$ & 0 & 0 & 0 & 0 & 0.21 & 0 & 0 & 0 & 0.81 & 0 & 0 & 0 \\
\hline $\mathrm{Hy}$ & 2.04 & 2.27 & 2.04 & 1.05 & 0.67 & 1.89 & 1.74 & 1.37 & 0 & 0.37 & 1.12 & 1.07 \\
\hline $\mathrm{Ilm}$ & 0.07 & 0.13 & 0.05 & 0.03 & 0.03 & 0.11 & 0.12 & 0.04 & 0.04 & 0.04 & 0.11 & 0.09 \\
\hline $\mathrm{Hem}$ & 2.88 & 2.66 & 2.44 & 1.8 & 1.5 & 2.16 & 2.07 & 2.12 & 1.57 & 2.33 & 2.46 & 1.9 \\
\hline $\mathrm{Ac}$ & 0 & 0 & 0 & 0 & 0 & 0 & 0 & 0 & 0 & 0 & 0 & 0 \\
\hline $\mathrm{Ap}$ & 0.14 & 0.44 & 0.32 & 0.09 & 0.05 & 0.42 & 0.56 & 0.28 & 0.02 & 0.02 & 0.09 & 0.09 \\
\hline $\mathrm{Tn}$ & 0.41 & 0 & 0 & 0 & 0.23 & 0 & 0 & 0 & 0.09 & 0 & 0 & 0 \\
\hline $\mathrm{Mt}$ & 0 & 0 & 0 & 0 & 0 & 0 & 0 & 0 & 0 & 0 & 0 & 0 \\
\hline
\end{tabular}

Trace elements (ppm)

\begin{tabular}{|c|c|c|c|c|c|c|c|c|c|c|c|c|}
\hline $\mathrm{U}$ & 5.3 & 4.8 & 3.8 & 4.7 & 5.5 & 4.5 & 2.2 & 5.6 & 41 & 16.9 & 17.3 & 40.9 \\
\hline $\mathrm{Th}$ & 13.6 & 13.2 & 15.9 & 20.2 & 27.4 & 26.9 & 20.3 & 23.3 & 167.1 & 100.9 & 31 & 90.7 \\
\hline $\mathrm{Cr}$ & 114 & 211 & 222 & 215 & 255 & 112 & 264 & 232 & 11 & 9 & 11 & 7 \\
\hline $\mathrm{Y}$ & 45.8 & 33.5 & 26.5 & 25.6 & 38.9 & 22.3 & 22.3 & 45.2 & 21.3 & 80.9 & 180.4 & 19.8 \\
\hline $\mathrm{Nb}$ & 15.11 & 15.46 & 14.23 & 13.25 & 12.62 & 9.88 & 8.45 & 15.21 & 696.62 & 180.98 & 151.41 & 450.62 \\
\hline $\mathrm{Zr}$ & 42.9 & 37.7 & 40 & 48.5 & 47.5 & 47.1 & 45.8 & 38.9 & 440.8 & 233.9 & 152 & 163.9 \\
\hline $\mathrm{Ni}$ & 115.6 & 121.5 & 87.9 & 116.2 & 62.3 & 119.8 & 162.1 & 142.1 & 5.1 & 4.6 & 6.3 & 5.1 \\
\hline $\mathrm{Ba}$ & 622 & 868 & 897 & 789 & 845 & 980 & 698 & 880 & 84 & 255 & 187 & 100 \\
\hline $\mathrm{Pb}$ & 105.6 & 68.17 & 66.1 & 68.9 & 77.2 & 82.3 & 45.6 & 40.6 & 17.86 & 36.22 & 31.39 & 15.07 \\
\hline $\mathrm{Rb}$ & 106.5 & 120.7 & 120.6 & 105.5 & 109.5 & 100.3 & 81.7 & 88.5 & 442 & 458 & 627.7 & 575 \\
\hline $\mathrm{Sr}$ & 240 & 255 & 285 & 272 & 270 & 244 & 270 & 286 & 25 & 36 & 78 & 22 \\
\hline $\mathrm{Zn}$ & 544.6 & 746.2 & 847.3 & 398.6 & 807.9 & 427.9 & 524.9 & 429.6 & 81.3 & 122.5 & 428 & 122.9 \\
\hline $\mathrm{Ti}$ & 0.48 & 0.69 & 0.63 & 0.48 & 0.66 & 0.67 & 0.45 & 0.66 & 1.2 & 2.15 & 2.32 & 2.13 \\
\hline $\mathrm{Cu}$ & 847.3 & 1220.8 & 1474.6 & 1252.3 & 1228.6 & 1668.5 & 886 & 549.5 & 40.6 & 9.8 & 13.9 & 26.5 \\
\hline $\mathrm{V}$ & 38 & 38 & 31 & 32 & 35 & 34 & 31 & 43 & 7 & 3 & 14 & 1 \\
\hline $\mathrm{Cs}$ & 0.7 & 1.4 & 1.2 & 0.9 & 1.6 & 0.8 & 1.4 & 1.6 & 1.9 & 1.8 & 6.2 & 5.9 \\
\hline $\mathrm{Be}$ & 3 & 2 & 2 & 2 & 3 & 3 & 2 & 2 & 3 & 7 & 8 & 3 \\
\hline $\mathrm{Sn}$ & 40.5 & 22.6 & 23.3 & 50.1 & 17.8 & 15.6 & 13.7 & 32.5 & 24.7 & 8.6 & 18.6 & 80.1 \\
\hline $\mathrm{Li}$ & 22.2 & 31 & 24.6 & 22.6 & 23.3 & 32.6 & 26.5 & 24.6 & 136.6 & 156.9 & 205.6 & 320.2 \\
\hline $\mathrm{Ta}$ & 0.7 & 1.6 & 0.8 & 0.8 & 0.7 & 0.6 & 0.6 & 0.8 & 90.4 & 18.9 & 13 & 84.9 \\
\hline $\mathrm{Co}$ & 9.2 & 9.4 & 7.6 & 6.8 & 7.8 & 8.3 & 8.9 & 9.8 & 1.1 & 0.8 & 2.6 & 0.6 \\
\hline $\mathrm{Hf}$ & 3.1 & 1.08 & 1.87 & 1.06 & 1.38 & 2.66 & 1.32 & 1.87 & 20.29 & 22.29 & 5.56 & 10.98 \\
\hline $\mathrm{Ga}$ & 21.09 & 20.9 & 20.66 & 19.88 & 19.92 & 21.03 & 19.79 & 21.22 & 57.24 & 40.2 & 42.6 & 39.3 \\
\hline
\end{tabular}

Rare earth elements (ppm)

\begin{tabular}{c|c|c|c|c|c|c|c|c|c|c|c|c}
\hline $\mathrm{La}$ & 32.60 & 31.30 & 40.10 & 37.50 & 34.50 & 50.60 & 52.90 & 32.20 & 9.6 & 8.9 & 20.9 & 8.9 \\
\hline $\mathrm{Ce}$ & 65.30 & 67.45 & 88.50 & 76.68 & 65.60 & 89.30 & 105.96 & 94.30 & 43.38 & 44.62 & 95.87 & 35.97 \\
\hline $\mathrm{Pr}$ & 8.30 & 8.10 & 12.90 & 9.10 & 8.90 & 11.90 & 12.80 & 7.20 & 4.1 & 7.5 & 10.3 & 3.8 \\
\hline $\mathrm{Nd}$ & 25.60 & 26.70 & 40.10 & 30.70 & 33.60 & 33.10 & 43.40 & 28.10 & 10.3 & 20.8 & 30.7 & 9.6 \\
\hline $\mathrm{Sm}$ & 5.40 & 5.30 & 6.50 & 7.20 & 6.90 & 6.20 & 7.40 & 7.10 & 2.5 & 2.4 & 10.1 & 1.6 \\
\hline $\mathrm{Eu}$ & 0.90 & 0.90 & 1.20 & 1.10 & 1.20 & 1.10 & 1.30 & 1.20 & $<0.1$ & 0.3 & 0.4 & $<0.1$ \\
\hline $\mathrm{Gd}$ & 5.20 & 5.10 & 6.70 & 5.70 & 6.30 & 4.80 & 5.50 & 6.10 & 1.4 & 4.6 & 8.6 & 3.8 \\
\hline $\mathrm{Tb}$ & 0.80 & 1.00 & 1.00 & 0.90 & 1.10 & 0.90 & 0.70 & 0.90 & 0.4 & 0.5 & 2.7 & 1.3 \\
\hline $\mathrm{Dy}$ & 5.70 & 5.90 & 6.60 & 6.30 & 5.70 & 3.90 & 3.50 & 3.40 & 3.6 & 4.7 & 21.5 & 20.3 \\
\hline $\mathrm{Ho}$ & 1.30 & 1.30 & 1.50 & 1.30 & 1.50 & 0.90 & 0.80 & 0.80 & 1.1 & 1 & 5.8 & 0.9 \\
\hline $\mathrm{Er}$ & 4.20 & 4.00 & 4.70 & 4.00 & 3.90 & 2.70 & 2.40 & 2.60 & 5.3 & 5.9 & 20.5 & 5.9 \\
\hline $\mathrm{Yb}$ & 4.80 & 4.9 & 5.1 & 4.80 & 4.80 & 2.5 & 2.6 & 2.00 & 13.5 & 5.9 & 27.2 & 13.6 \\
\hline $\mathrm{Lu}$ & 0.6 & 0.7 & 0.8 & 0.6 & 0.7 & 0.4 & 0.4 & 0.3 & 0.3 & 0.3 & 0.3 & 0.3 \\
\hline $\mathrm{Tm}$ & 0.7 & 0.7 & 0.8 & 0.7 & 0.7 & 0.4 & 0.4 & 0.4 & 1.4 & 1.4 & 4.1 & 1 \\
\hline
\end{tabular}

Geochemical Parameters

\begin{tabular}{c|c|c|c|c|c|c|c|c|c|c|c|c}
\hline $\mathrm{Zr} / \mathrm{Hf}$ & 13.8 & 34.9 & 21.4 & 45.8 & 34.4 & 17.70 & 34.7 & 20.8 & 21.72 & 10.49 & 27.34 & 14.93 \\
\hline
\end{tabular}




\begin{tabular}{|c|c|c|c|c|c|c|c|c|c|c|c|c|}
\hline $\mathrm{Zr} / \mathrm{Sr}$ & 0.2 & 0.1 & 0.1 & 0.2 & 0.2 & 0.2 & 0.2 & 0.1 & 17.63 & 6.50 & 1.95 & 7.45 \\
\hline $\mathrm{Rb} / \mathrm{Zr}$ & 2.5 & 3.2 & 3.0 & 2.2 & 2.3 & 2.1 & 1.8 & 2.3 & 1.0 & 1.96 & 4.13 & 3.51 \\
\hline $\mathrm{Rb} / \mathrm{Sr}$ & 0.4 & 0.5 & 0.4 & 0.4 & 0.4 & 0.4 & 0.3 & 0.3 & 17.68 & 12.72 & 8.05 & 26.14 \\
\hline $\mathrm{Sr} / \mathrm{Rb}$ & 2.3 & 2.1 & 2.4 & 2.6 & 2.5 & 2.4 & 3.3 & 3.2 & 0.06 & 0.08 & 0.12 & 0.04 \\
\hline $\mathrm{Y} / \mathrm{Nb}$ & 3.0 & 2.2 & 1.9 & 1.9 & 3.1 & 2.3 & 2.6 & 3.0 & 0.03 & 0.45 & 1.19 & 0.04 \\
\hline $\mathrm{Nb} / \mathrm{Ta}$ & 21.6 & 9.7 & 17.80 & 16.60 & 18.0 & 21.50 & 14.10 & 19.0 & 7.70 & 9.6 & 11.6 & 5.3 \\
\hline $\mathrm{Yb} / \mathrm{Ta}$ & 6.9 & 3.1 & 6.4 & 6.0 & 6.9 & 4.2 & 4.3 & 2.5 & 0.15 & 0.31 & 2.09 & 0.16 \\
\hline $\mathrm{Ba} / \mathrm{Rb}$ & 5.8 & 7.2 & 7.4 & 7.5 & 7.7 & 9.8 & 8.5 & 9.9 & 0.19 & 0.56 & 0.30 & 0.17 \\
\hline $\mathrm{Eu} / \mathrm{Sm}$ & 0.2 & 0.2 & 0.2 & 0.2 & 0.2 & 0.2 & 0.2 & 0.2 & 0.04 & 0.13 & 0.04 & 0.06 \\
\hline $\mathrm{K} / \mathrm{Rb}$ & 337.5 & 267.8 & 267.80 & 370.60 & 360.1 & 367.50 & 337.30 & 437.10 & 67.61 & 69.96 & 58.59 & 65.69 \\
\hline $\mathrm{Rb} / \mathrm{Ba}$ & 0.2 & 0.1 & 0.1 & 0.1 & 0.1 & 0.1 & 0.1 & 0.1 & 5.26 & 1.80 & 3.36 & 5.75 \\
\hline $\mathrm{K} / \mathrm{Ba}$ & 57.8 & 37.0 & 36.0 & 49.60 & 46.70 & 37.60 & 39.50 & 44.0 & 355.77 & 125.7 & 196.66 & 377.71 \\
\hline$\sum \mathrm{REEs}$ & 161.40 & 163.35 & 216.50 & 186.58 & 175.40 & 208.70 & 240.06 & 186.60 & 90.55 & 104.9 & 244.36 & 102.66 \\
\hline$\sum$ LREEs & 138.10 & 139.75 & 189.30 & 162.28 & 150.70 & 190.20 & 223.76 & 170.10 & 61.65 & 75.95 & 149.86 & 53.06 \\
\hline$\sum$ HREEs & 23.30 & 23.60 & 27.20 & 24.30 & 24.70 & 16.50 & 16.30 & 16.50 & 28.90 & 29.0 & 94.50 & 49.60 \\
\hline $\begin{array}{c}\sum \text { LREEs } \\
/ \sum \text { HREEs }\end{array}$ & 5.93 & 5.92 & 6.96 & 6.68 & 6.10 & 11.65 & 13.73 & 10.31 & 2.13 & 2.62 & 1.59 & 1.07 \\
\hline $\mathrm{Eu} / \mathrm{Eu}^{*}$ & 0.52 & 0.53 & 0.56 & 0.52 & 0.56 & 0.62 & 0.62 & 0.56 & 0.16 & 0.28 & 0.13 & 0.12 \\
\hline$(\mathrm{La} / \mathrm{Sm})_{\mathrm{n}}$ & 380 & 3.71 & 3.88 & 3.28 & 3.15 & 5.13 & 4.50 & 2.85 & 2.42 & 2.33 & 1.30 & 3.50 \\
\hline$(\mathrm{La} / \mathrm{Yb})_{\mathrm{n}}$ & 4.58 & 4.31 & 5.30 & 5.27 & 4.85 & 13.65 & 13.72 & 10.85 & 0.48 & 1.02 & 0.52 & 0.44 \\
\hline$(\mathrm{Ce} / \mathrm{Yb})_{\mathrm{n}}$ & 3.52 & 3.56 & 4.49 & 4.13 & 3.54 & 9.24 & 10.54 & 12.20 & 0.67 & 1.58 & 0.74 & 0.55 \\
\hline$(\mathrm{Eu} / \mathrm{Yb})_{\mathrm{n}}$ & 0.53 & 0.52 & 0.67 & 0.65 & 0.71 & 1.25 & 1.42 & 1.71 & 0.02 & 0.14 & 0.04 & 0.02 \\
\hline$(\mathrm{Tb} / \mathrm{Yb})_{\mathrm{n}}$ & 0.7 & 0.9 & 0.9 & 0.8 & 1.0 & 1.6 & 1.2 & 2.0 & 0.6 & 0.4 & 0.04 & 0.4 \\
\hline $\mathrm{TE}_{1}$ & 1.11 & 1.11 & 1.16 & 1.07 & 0.97 & 1.09 & 1.06 & 1.19 & 1.66 & 1.66 & 1.53 & 1.56 \\
\hline $\mathrm{TE}_{3}$ & 0.91 & 1.04 & 0.89 & 0.97 & 0.90 & 0.99 & 0.82 & 0.87 & 1.07 & 0.79 & 1.19 & 3.07 \\
\hline $\mathrm{TE}_{1.3}$ & 1.0 & 1.08 & 1.02 & 1.02 & 0.94 & 1.04 & 0.93 & 1.02 & 1.33 & 1.14 & 1.35 & 2.19 \\
\hline
\end{tabular}

Table 1 (Continued)

\begin{tabular}{c|c|c|c|c|c|c|c|c|c|c}
\hline \multicolumn{9}{c}{ Pegmatites veins } \\
\hline S. No. & B11 & B13 & B15 & B18 & B20 & B23 & B25 & B27 & B30 \\
\hline Major oxides \\
\hline $\mathrm{SiO}_{2}$ & 76.5 & 76.39 & 74.92 & 75.72 & 75.62 & 75.97 & 75.83 & 75.54 & 73.85 \\
\hline $\mathrm{TiO}_{2}$ & 0.09 & 0.03 & 0.09 & 0.04 & 0.15 & 0.02 & 0.04 & 0.02 & 0.09 \\
\hline $\mathrm{Al}_{2} \mathrm{O}_{3}$ & 11.77 & 11.45 & 12.75 & 11.98 & 12.17 & 12.34 & 11.15 & 12.36 & 12.98 \\
\hline $\mathrm{Fe}_{2} \mathrm{O}_{3}$ & 1.84 & 1.03 & 1.82 & 1.74 & 1.82 & 1.9 & 2.67 & 2.14 & 1.85 \\
\hline $\mathrm{MnO}$ & 0.1 & 0.02 & 0.1 & 0.01 & 0.1 & 0.02 & 0.12 & 0.13 & 0.03 \\
\hline $\mathrm{MgO}$ & 0.07 & 0.05 & 0.07 & 0.07 & 0.03 & 0.03 & 0.07 & 0.02 & 0.06 \\
\hline $\mathrm{CaO}$ & 0.34 & 0.18 & 0.32 & 0.21 & 0.09 & 0.06 & 0.08 & 0.01 & 0.18 \\
\hline $\mathrm{Na}_{2} \mathrm{O}$ & 3.24 & 4.46 & 3.99 & 4.57 & 4.26 & 4.97 & 4.13 & 5.11 & 4.08 \\
\hline $\mathrm{K}_{2} \mathrm{O}$ & 4.75 & 4.01 & 4.3 & 3.85 & 4.66 & 4.1 & 4.2 & 4.22 & 4.84 \\
\hline $\mathrm{P}_{2} \mathrm{O}_{5}$ & 0.01 & 0.01 & 0.04 & 0.04 & 0.01 & 0.01 & 0.01 & 0.01 & 0.04 \\
\hline $\mathrm{L} . \mathrm{O} . \mathrm{I}$ & 1.02 & 1.37 & 1.40 & 1.80 & 0.89 & 0.41 & 1.30 & 0.44 & 1.6 \\
\hline $\mathrm{Total}$ & 99.73 & 99.00 & 99.80 & 99.63 & 99.80 & 99.83 & 99.60 & 99.99 & 99.60 \\
\hline $\mathrm{CIPW}$ norm3 & & & & & & & \\
\hline $\mathrm{Qz}$ & 38.67 & 35.12 & 34.58 & 33.91 & 32.81 & 31.6 & 35.78 & 30.36 & 31.23 \\
\hline $\mathrm{Or}$ & 28.07 & 23.7 & 25.41 & 22.75 & 27.54 & 24.23 & 24.82 & 24.94 & 28.6 \\
\hline $\mathrm{Ab}$ & 27.42 & 36.57 & 33.76 & 38.67 & 36.05 & 40.65 & 33.97 & 40.08 & 43.52 \\
\hline $\mathrm{An}$ & 1.62 & 0 & 1.3 & 0.8 & 0.32 & 0 & 0 & 0 & 0.63 \\
\hline $\mathrm{C}$ & 0.7 & 0 & 1.05 & 0 & 0 & 0 & 0 & 0 & 0.8 \\
\hline $\mathrm{Di} / \mathrm{Wo}$ & 0 & 0.19 & 0 & 0 & 0 & 0.01 & 0 & 0 & 0 \\
\hline
\end{tabular}




\begin{tabular}{c|c|c|c|c|c|c|c|c|c}
\hline Di /en & 0 & 0.27 & 0 & 0.06 & 0 & 0.16 & 0.26 & 0 & 0 \\
\hline Hy & 0.17 & 0 & 0.17 & 0.15 & 0.07 & 0 & 0.05 & 0.05 & 0.15 \\
\hline $\mathrm{Ilm}$ & 0.17 & 0.04 & 0.17 & 0.02 & 0.21 & 0.04 & 0.08 & 0.04 & 0.06 \\
\hline $\mathrm{Hem}$ & 1.79 & 0.67 & 1.77 & 1.74 & 1.82 & 1.47 & 2.18 & 0.93 & 1.85 \\
\hline $\mathrm{Ac}$ & 0 & 1.03 & 0 & 0 & 0 & 1.24 & 0.86 & 2.78 & 0 \\
\hline $\mathrm{Ap}$ & 0.02 & 0.02 & 0.09 & 0.02 & 0.02 & 0.02 & 0.02 & 0.02 & 0.09 \\
\hline $\mathrm{Tn}$ & 0 & 0.02 & 0 & 0.07 & 0.04 & 0 & 0 & -0.01 & 0 \\
\hline $\mathrm{Mt}$ & 0.07 & 0 & 0.07 & 0 & 0 & 0.01 & 0.28 & 0.37 & 0 \\
\hline
\end{tabular}

Trace elements (ppm)

\begin{tabular}{|c|c|c|c|c|c|c|c|c|c|}
\hline $\mathrm{U}$ & 6.9 & 44.6 & 30.9 & 5.8 & 33.9 & 13.3 & 21.8 & 28.5 & 31 \\
\hline Th & 60.3 & 85.8 & 109.5 & 22 & 119.6 & 34.3 & 101.5 & 215.2 & 110.6 \\
\hline $\mathrm{Cr}$ & 10 & 6 & 8 & 7 & 10 & 6 & 9 & 17 & 11 \\
\hline $\mathrm{Y}$ & 89.9 & 13.2 & 26.5 & 26.9 & 23.9 & 20 & 27.5 & 20.6 & 130.5 \\
\hline $\mathrm{Nb}$ & 198.43 & 532.45 & 190.84 & 180.94 & 366.79 & 448.96 & 610.63 & 1425.36 & 532.61 \\
\hline $\mathrm{Zr}$ & 133.2 & 390.3 & 255.1 & 285.8 & 365.8 & 291 & 554.1 & 428.8 & 390.8 \\
\hline $\mathrm{Ni}$ & 2.5 & 3.2 & 3.8 & 3.1 & 4.8 & 2.8 & 3.6 & 5.7 & 6.1 \\
\hline $\mathrm{Ba}$ & 239 & 72 & 80 & 55 & 190 & 52 & 50 & 71 & 235 \\
\hline $\mathrm{Pb}$ & 259.85 & 16.17 & 18.35 & 9.34 & 244.5 & 11.35 & 35.22 & 536.36 & 8.69 \\
\hline $\mathrm{Rb}$ & 995.2 & 475 & 522.9 & 530.8 & 599 & 571.2 & 880.1 & 898.8 & 330.8 \\
\hline $\mathrm{Sr}$ & 48 & 17 & 22 & 16 & 66 & 18 & 7 & 23 & 55 \\
\hline $\mathrm{Zn}$ & 183.7 & 67.6 & 91.3 & 100.8 & 263.9 & 116.3 & 345.4 & 1770.7 & 263.5 \\
\hline $\mathrm{Ti}$ & 2.56 & 1.25 & 2.34 & 1.8 & 1.88 & 1.79 & 2.16 & 2.35 & 2.42 \\
\hline $\mathrm{Cu}$ & 36.3 & 39.1 & 13.3 & 16.2 & 13.5 & 31.1 & 6.6 & 536 & 30.6 \\
\hline $\mathrm{V}$ & 2 & 2 & 7 & 3 & 12 & $<1$ & 1 & $<1$ & 2 \\
\hline Cs & 3.5 & 1.8 & 3.6 & 2.9 & 3.9 & 2.8 & 5.3 & 2.4 & 3.5 \\
\hline $\mathrm{Be}$ & 5 & 3 & 5 & 4 & 8 & 4 & 3 & 1 & 4 \\
\hline $\mathrm{Sn}$ & 95.1 & 18.8 & 32.8 & 7.9 & 30.7 & 23.7 & 33.8 & 50.2 & 87.3 \\
\hline $\mathrm{Li}$ & 476.3 & 72.5 & 309.6 & 116.5 & 689.3 & 102 & 1619.2 & 690.2 & 985.3 \\
\hline $\mathrm{Ta}$ & 16.4 & 71 & 19.9 & 15.2 & 63.8 & 49.1 & 79.9 & 171.4 & 70.9 \\
\hline $\mathrm{Co}$ & 0.3 & 0.5 & 0.5 & 0.6 & 0.9 & $<0.2$ & 0.4 & 0.5 & 1.1 \\
\hline Hf & 6.9 & 18.77 & 11.9 & 10.39 & 5.7 & 11.76 & 29.59 & 27.56 & 13.2 \\
\hline $\mathrm{Ga}$ & 38.03 & 54.31 & 48.9 & 36.16 & 33.9 & 69.34 & 59.3 & 65.45 & 40.9 \\
\hline
\end{tabular}

Rare earth elements (ppm)

\begin{tabular}{c|c|c|c|c|c|c|c|c|c}
\hline $\mathrm{La}$ & 18.8 & 9.3 & 6.8 & 5.1 & 17.3 & 2.6 & 5.7 & 2.4 & 6.9 \\
\hline $\mathrm{Ce}$ & 48.88 & 39.35 & 60.5 & 23.85 & 30.88 & 14.22 & 28.97 & 12.13 & 75.19 \\
\hline $\mathrm{Pr}$ & 6.1 & 4.6 & 5.9 & 2.8 & 6.1 & 1.7 & 3.7 & 1.5 & 8.9 \\
\hline $\mathrm{Nd}$ & 20.8 & 10.3 & 10.3 & 6.3 & 29.9 & 3.3 & 8.2 & 3.1 & 25.39 \\
\hline $\mathrm{Sm}$ & 5.4 & 2.6 & 1.1 & 1.7 & 0.9 & 1.1 & 2.3 & 0.9 & 5.9 \\
\hline $\mathrm{Eu}$ & 0.3 & $<0.1$ & 0.3 & $<0.1$ & 0.4 & $<0.1$ & $<0.1$ & $<0.1$ & 0.4 \\
\hline $\mathrm{Gd}$ & 4.6 & 1.1 & 5.6 & 1.1 & 1.4 & 0.6 & 1.1 & 0.7 & 6.8 \\
\hline $\mathrm{Tb}$ & 1.3 & 0.5 & 2.1 & 0.4 & 0.2 & 0.4 & 0.5 & 0.3 & 1.5 \\
\hline $\mathrm{Dy}$ & 10.2 & 3 & 10.6 & 3.6 & 9.8 & 3 & 4.7 & 3.5 & 11.6 \\
\hline $\mathrm{Ho}$ & 2.5 & 0.9 & 0.9 & 1 & 2.9 & 1 & 1.4 & 1.1 & 1.4 \\
\hline $\mathrm{Er}$ & 9.8 & 4.1 & 11.3 & 3.9 & 12.4 & 3.9 & 5.5 & 5.9 & 19.5 \\
\hline $\mathrm{Yb}$ & 20.1 & 9.2 & 14.9 & 6.9 & 13.4 & 7.1 & 13.4 & 15.6 & 27.2 \\
\hline $\mathrm{Lu}$ & 0.3 & 0.3 & 0.3 & 0.3 & 0.3 & 0.3 & 0.3 & 0.3 & 0.3 \\
\hline $\mathrm{Tm}$ & 2.8 & 1 & 1.4 & 1 & 1 & 0.9 & 1.6 & 1.7 & 2.8 \\
\hline $\mathrm{Geochemical} \mathrm{Parameters}$ & & & & & & & & \multicolumn{2}{|c}{} \\
\hline $\mathrm{Zr} / \mathrm{Hf}$ & 19.30 & 20.79 & 21.44 & 27.51 & 64.18 & 24.74 & 18.73 & 15.56 & 29.61 \\
\hline $\mathrm{Zr} / \mathrm{Sr}$ & 2.78 & 22.96 & 11.60 & 17.86 & 5.54 & 16.17 & 79.16 & 18.64 & 7.11 \\
\hline
\end{tabular}




\begin{tabular}{c|c|c|c|c|c|c|c|c|c}
\hline $\mathrm{Rb} / \mathrm{Zr}$ & 7.47 & 1.22 & 2.05 & 1.86 & 1.64 & 1.96 & 1.59 & 2.10 & 0.85 \\
\hline $\mathrm{Rb} / \mathrm{Sr}$ & 20.73 & 27.94 & 23.77 & 33.18 & 9.08 & 31.73 & 125.73 & 39.08 & 6.01 \\
\hline $\mathrm{Sr} / \mathrm{Rb}$ & 0.05 & 0.04 & 0.04 & 0.03 & 0.11 & 0.03 & 0.01 & 0.03 & 0.17 \\
\hline $\mathrm{Y} / \mathrm{Nb}$ & 0.45 & 0.02 & 0.14 & 0.15 & 0.07 & 0.04 & 0.05 & 0.01 & 0.25 \\
\hline $\mathrm{Nb} / \mathrm{Ta}$ & 12.10 & 7.5 & 9.6 & 11.90 & 5.8 & 9.1 & 7.6 & 8.30 & 7.5 \\
\hline $\mathrm{Yb} / \mathrm{Ta}$ & 1.23 & 0.13 & 0.75 & 0.45 & 0.21 & 0.14 & 0.17 & 0.09 & 0.38 \\
\hline $\mathrm{Ba} / \mathrm{Rb}$ & 0.24 & 0.15 & 0.15 & 0.10 & 0.32 & 0.09 & 0.06 & 0.08 & 0.71 \\
\hline $\mathrm{Eu} / \mathrm{Sm}$ & 0.06 & 0.04 & 0.27 & 0.06 & 0.44 & 0.09 & 0.04 & 0.11 & 0.07 \\
\hline $\mathrm{K} / \mathrm{Rb}$ & 39.62 & 70.08 & 68.26 & 60.21 & 64.58 & 59.59 & 39.62 & 38.98 & 121.46 \\
\hline $\mathrm{Rb} / \mathrm{Ba}$ & 4.16 & 6.60 & 6.54 & 9.65 & 3.15 & 10.98 & 17.60 & 12.66 & 1.41 \\
\hline $\mathrm{K} / \mathrm{Ba}$ & 164.98 & 462.34 & 446.19 & 581.09 & 203.60 & 654.56 & 697.31 & 493.40 & 170.97 \\
\hline $\mathrm{RREEs}$ & 79.57 & 87.65 & 135.0 & 58.85 & 130.18 & 41.02 & 79.57 & 51.53 & 193.18 \\
\hline$\sum \mathrm{LREEs}$ & 100.28 & 66.25 & 48.97 & 39.85 & 85.48 & 23.02 & 48.97 & 20.13 & 122.68 \\
\hline$\sum \mathrm{HREEs}$ & 54.90 & 21.40 & 30.60 & 19.0 & 44.70 & 18.0 & 30.60 & 31.40 & 70.50 \\
\hline$\sum \mathrm{LREEs}$ & 1.83 & 3.10 & 1.60 & 2.10 & 1.91 & 1.28 & 1.60 & 0.64 & 1.74 \\
\hline $\mathrm{\Sigma HREEs}$ & & & & & & & & & \\
\hline $\mathrm{Eu} / \mathrm{Eu} *$ & 0.18 & 0.18 & 0.37 & 0.22 & 1.09 & 0.38 & 0.19 & 0.39 & 0.19 \\
\hline$(\mathrm{La} / \mathrm{Sm})_{\mathrm{n}}$ & 2.19 & 2.25 & 3.89 & 1.89 & 12.09 & 1.49 & 1.56 & 1.68 & 0.74 \\
\hline$(\mathrm{La} / \mathrm{Yb})_{\mathrm{n}}$ & 0.63 & 0.68 & 0.31 & 0.50 & 0.87 & 0.25 & 0.29 & 0.1 & 0.17 \\
\hline$(\mathrm{Ce} / \mathrm{Yb})_{\mathrm{n}}$ & 0.63 & 1.11 & 1.05 & 0.89 & 0.60 & 0.52 & 0.56 & 0.2 & 0.72 \\
\hline$(\mathrm{Eu} / \mathrm{Yb})_{\mathrm{n}}$ & 0.04 & 0.03 & 0.06 & 0.04 & 0.08 & 0.04 & 0.02 & 0.02 & 0.04 \\
\hline$(\mathrm{Tb} / \mathrm{Yb})_{\mathrm{n}}$ & 0.3 & 0.2 & 0.6 & 0.3 & 0.1 & 0.2 & 0.2 & 0.1 & 0.2 \\
\hline $\mathrm{TE} \mathrm{F}_{1}$ & 1.20 & 1.89 & 3.10 & 1.98 & 0.83 & 2.31 & 2.08 & 2.15 & 2.68 \\
\hline $\mathrm{TE}{ }_{3}$ & 1.19 & 1.36 & 2.32 & 1.26 & 0.77 & 1.56 & 1.36 & 1.29 & 1.49 \\
\hline $\mathrm{TE} \mathrm{I}_{1.3}$ & 1.19 & 1.60 & 2.68 & 1.58 & 0.80 & 1.90 & 1.68 & 1.66 & 2.0 \\
\hline
\end{tabular}





Figure 9a): $\mathrm{Na} 2 \mathrm{O}+\mathrm{K} 2 \mathrm{O}$ vs. $\mathrm{SiO} 2$ variation diagram [11]. Symbols are the same for all next diagrams ( Omonzogranite and $\diamond$ pegmatites of G. El Fereyid - W. Rahaba area), b): R1-R2 diagram after [12], c): Ba vs $\mathrm{K} / \mathrm{Rb}$ diagram according to Mehnert and Busch [13], d): Li vs K/Rb diagram according to Cerny and Burt [25], e): Molar Al2O3/(CaO+Na2O+K2O) versus Al2O3/(Na2O+K2O) [14] and f): Alkali-SiO2 variation diagram [26], G. El Fereyid - W. Rahaba, South Eastern Desert, Egypt. 

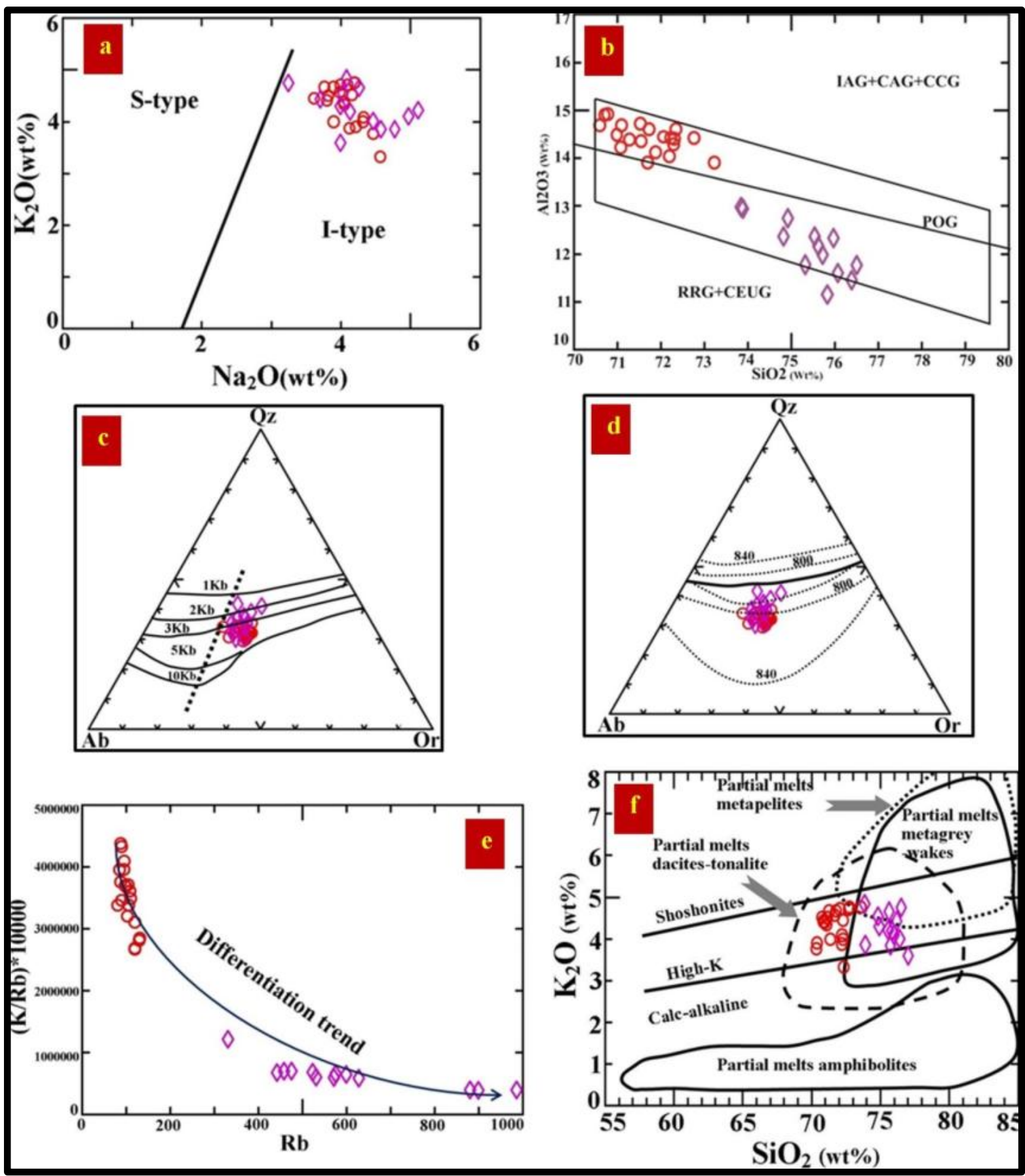

Figure 10. a): Na2O-K2O discrimination diagram after [15], b): $\mathrm{SiO} 2$ vs Al2O3 diagram after [14], c): Normative Qz-Ab-Or ternary giagram. The dashed line represents the variation in position of the minimum melting points in the granite system at different water vapor pressures. [16] and [17], d): Normative Qz-Ab-Or isobaric equilibrium ternary diagram after [16], e): K/Rb versus Rb binary diagram of the studied samples and f): $\mathrm{K} 2 \mathrm{O}$ - $\mathrm{SiO} 2$ diagram. Field of partial melts of different rock sources are after [27], G. El Fereyid - W. Rahaba, South Eastern Desert, Egypt. 


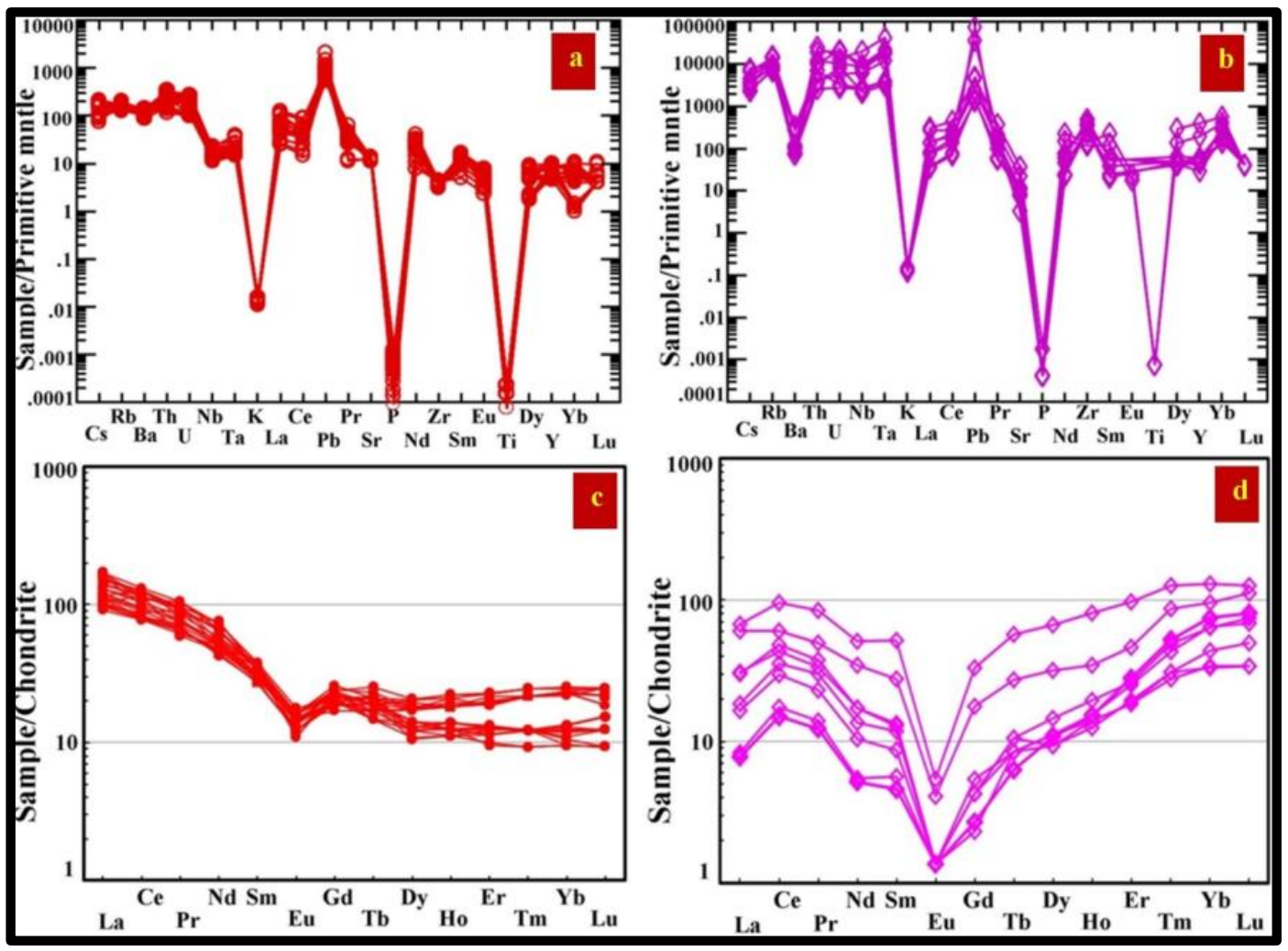

Figure 11. a): Normalized multi-elements patterns of the monzogranite [18], b): Normalized multi-elements patterns of the pegmatites [18], c): Rare earth element distribution pattern of monzogranite. Normalized to chondrite of [20] and d): Rare earth element distribution pattern of pegmatites. Normalized to chondrite of [20], G. El Fereyid - W. Rahaba, South Eastern Desert, Egypt.

\section{Conclusions}

The basement rocks exposed in the area include tonalities, monzogranite and pegmatites. Tonalites are whitish grey to grey, medium to coarse-grained, variable strained, highly weathered and exfoliated and porphyritic texture. It consists of plagioclase, K-feldspar and, quartz associated with mafic minerals as hornblende and biotite. Monzogranite forms the main granitic masses of G. El Fereyid - W. Rahaba that is elongated in NW- SE directions. Monzogranite is leucocratic, medium to coarse-grained, massive, jointed, exfoliated, pinkish grey in color and highly sheared and composed essentially of potash feldspar, plagioclase, quartz as well as the mafic minerals. Pegmatite can be considered as the most abundant rock units bearing anomalous radioactive signature. The studied pegmatitic rocks occur as a vein type (granitic and perthitic pegmatites) hosted within the monzogranite.The general trend of the study younger granites suggests that pegmatite rock unit is the most differentiated in the study area and the studied younger granites of G. El Fereyid are low calcium, iron oxides and $\mathrm{MgO}$ contents but they are rich in alkalies (Potassium and sodium oxides). Monzogranite shows enrichment (peaks) of large ion lithophile elements (LILE; Pb, Rb, Ba, Sr) and high field strength elements (HFSE; Y, Zr, Nd,) and depletion (troughs) of K, P and Ti. Pegmatite shows enrichment (peaks) of large ion lithophile elements (LILE; $\mathrm{Pb}, \mathrm{Rb}, \mathrm{Sr}$ ) and high field strength elements (HFSE; Y, Zr, Th, U, Nb) and depletion (troughs) of $\mathrm{K}, \mathrm{P}$ and $\mathrm{Ti}$. 


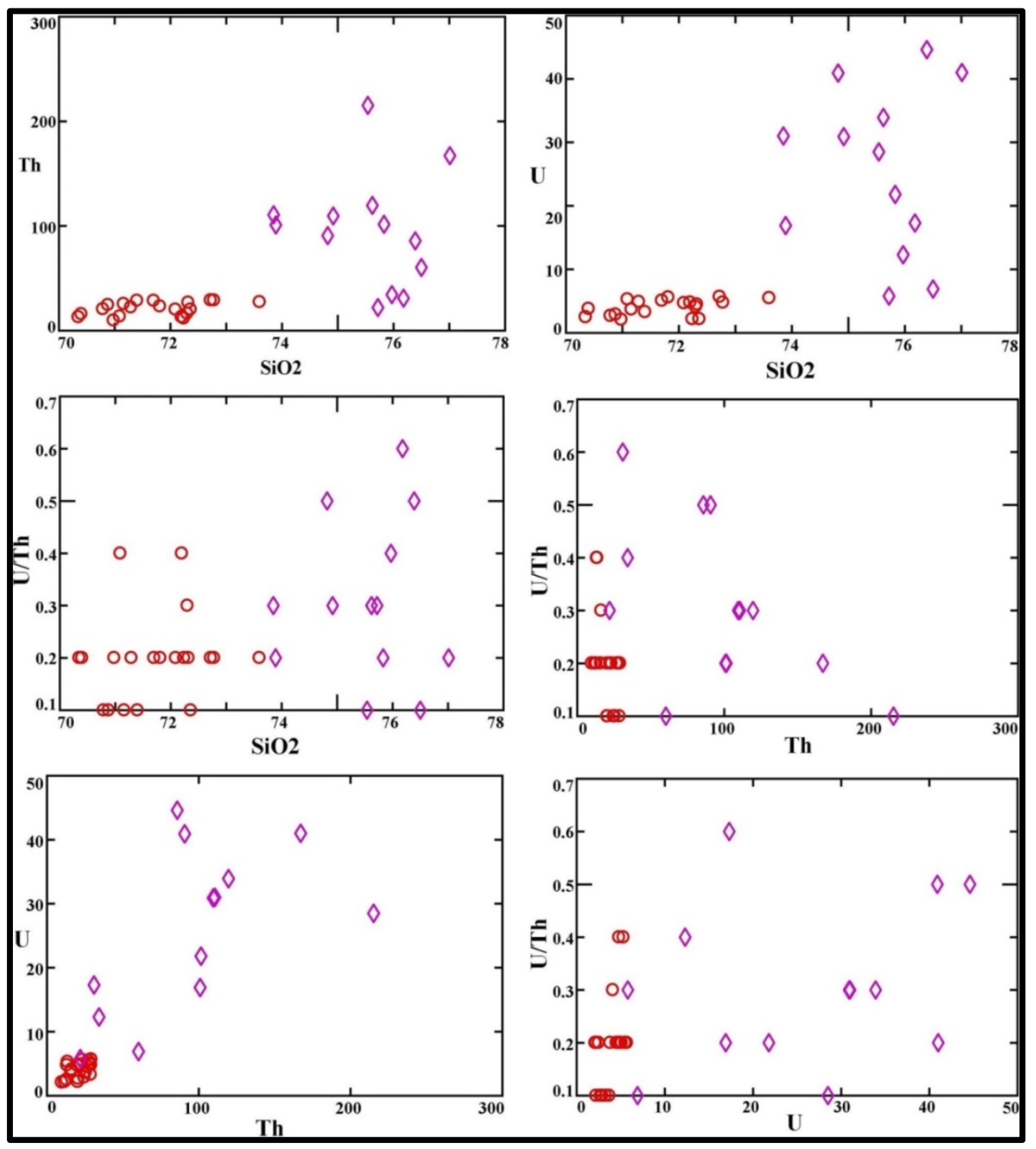

Figure 12. Correlation between U, Th and U/Th ratio for monzogranite and pegmatites, G. El Fereyid - W. Rahaba, South Eastern Desert, Egypt.

They exhibit high K-calc alkaline magma and peraluminous characteristics and also considered as post orogenic granites (POG) and formed as a result of partial melting of the lower crust that was mainly amphibolites. The estimated temperature, using both the apatite and zircon models, is 760-840 C. This temperature is consistent with partial melting reactions of amphibole-bearing rock at depths of $>30 \mathrm{~km}$. They were subjected to many alteration processes including silicification, kaolinization and hematitization. The monzogranite reveal small to moderate negative Eu anomaly, while the pegmatite reveal moderate to large negative Eu anomaly. Hydrothermal alteration during post-magmatic stages is also identified through the development of a W-type tetrad effect in the REE pattern of pegmatite. The distinct behavior of the most popular isovalent elements ratio ( $\mathrm{Zr} / \mathrm{Hf}, \mathrm{Nb} / \mathrm{Ta}, \mathrm{Th} / \mathrm{U}, \mathrm{Y} / \mathrm{Ho}$ ) during hydrothermal alteration seems to be non-chondritic and is no longer exclusive the control of ionic radius and charge.

Acknowledgments. The authors would like to thank the all my colleagues in the Department of Radioactive granitic deposits (Nuclear Materials Authority, Cairo, Egypt) and Abu Ramad project (2015-2018) for their help during the work and available facilities. 


\section{References}

1. H. H. Abd El Naby and G.M. Saleh, Radioelement distribution in the proterozoic granites and associated pegmatites of Gabal El Fereyid area, Southeastern Desert, Egypt, Applied Radiation and Isotopes 59, pp. 289299, 2003.

2. R. J. Walker, The origin of the Tin Mountain pegmatite, Black Hills, South Dakota: Unpubl. Ph.D.thesis, State University of New York at Stony Brook, 170 pp, 1984.

3. R. Thomas and J. D. Webster, Characteristics of berlinite from the Ehrenfriedersdorf pegmatite, Erzgebirge, Germany: European Journal of Mineralogy, v. 281, pp. 124-136, 2000.

4. G. M. Sosa, M. S. Augsburger and J. S. Pedregosa, Columbite-group minerals from rare-metal granitic pegmatites of the Sierra de San Luis, Argentina: European Journal of Mineralogy, v. 14, p. 627-636, 2004.

5. L. R. Page, Uranium in pegmatites. Econ. Geol. 45, pp.12-34, 1950.

6. H. M. E. Shurmann, The Precambrian along the Gulf of Suez and the Northern Part of the Red Sea [M]. E.J. Brill, Leiden, Netherlands, pp.122-142, 1966.

7. M. H. El Baraga, Geolgical, mineralogical and geochemical studies of the Precamrian rocks around Wadi Rahaba, South Eastern Desert, Egypt. PhD Geol, Fac Sci, Tanta Univ, Egypt, 278pp, 19992.

8. M. A. El Amawy, Structure and tectonic development of Wadi Beitan, Wadi Rahaba area, South Eastern Desert, Egypt. 9th Symp Precambrian Develop, Nat Comitt Geol Sci, Cairo, Egypt, pp.9, 1991.

9. M. A. F. M. El Eraqi, Geophysical study on the area between Latitudes 23 00-25 N and Longitudes 33 30-35 30 E, Southeastern Desert, Egypt. PhD Geophy, Fac Sci, Zagazig Univ, 289 pp, 1990.

10.A. M. Abdel Karim and E. A. Sos, Geochemical characteristics and potassium argon ages dating of some granitoids from South Eastern Desert, Egypt. Egypt J Geol Soc Egypt, Cairo. Egypt V.44, No. 1, pp. 305-318, 2000 .

11.E. R. Middlemost, Magmas and magmatic rocks: An introduction to igneous petrology. Longman, Singapore, pp.161-162, 1985.

12.H. De La Roche, J. Leterrier, P. Grandclaude and M. Marchal, A classification of volcanic and plutonic rocks using R1-R2 diagram and major element analysis; its relationships with current nomenclature. Chem. Geol., v. 29, pp. 183-210, 1980.

13.K. R. Mehnert, and W. Busch, The Ba content of K-feldspar megacrysts in granites. Neus Jahrbuch Mineralogie Abhandlung, v. 140, pp. 221-252, 1981.

14.P. D. Maniar, and P. M. Piccoli, Tectonic discrimination of granitoids., Geol. Soc. Am. Bull., vol. 101, pp. 635$643,1989$.

15.B. W. Chappell and A. J. R. White, Two contrasting granite types. Pacific Geology, Vol. 8, pp. 173-174, 1974.

16.O. F. Tuttle and W. L. Bowen, Origin of granite in the light of experimental studies in the system NaAlSi3O8KAlSi3O8-SiO2-H2O. Geol. Soc. Amer. Mem. 74, 1958.

17.W. C. Luth, R. H. Jahns and O. F. Tuttle, The granite system at pressures of 4 to 10 kilobars. Journal of Geophysical Research 69, pp. $759-773,1964$.

18.S. S. Sun, and W. F. McDonough, Chemical and isotopic systematics of oceanic basalts: Implications for mantle composition and processes. In: Saunders, A. D. and Norry, M. J. (eds.): Magmatism in the ocean basins. Geol. Soc. London. Spec. Publ. 42, pp. 313-345, 1989.

19.R. L. Cullers and 1. Graf, Rare Earth elements in igneous rocks of the continental crust: Intermediate and silicic rocks are petrogenesis. In: Henderson, P. (ed.) Rare Earth Elements Geochemistry. Elsevier Pub. Co., Amsterdam, Vol. 2, pp. 275-316, 1984.

20.W. V. Boynton, Geochemistry of the rare earth elements: meteorite studies In: Henderson, P. (ed.) Rare earth element geochemistry [M]. Elsevier, Amsterdam. pp. 63-114, 1984.

21.A. Masuda, O. Kawakami, Y. Dohmoto, and T. Takenaka, Lanthanide tetrad effects in nature: Two mutually opposite types, W and M. J. Geochem. J. 21, pp.119- 124, 1987.

22.W. Irber, The lanthanide tetrad effect and its correlation with $\mathrm{K} / \mathrm{Rb}, \mathrm{Eu} / \mathrm{Eu}^{*}, \mathrm{Sr} / \mathrm{Eu}, \mathrm{Y} / \mathrm{Ho}$ and $\mathrm{Zr} / \mathrm{Hf}$ of evolving peraluminous granite suites. Geochemica. et Cosmochimica Acta, 63 (3), pp. 489- 508, 1999.

23.M. Bau, Controls on the fractionation of isovalent trace elements in magmatic and aqueous system; evidence from Y/Ho, Zr/Hf and lanthanide tetrad effect. Contrib. Mineral Petrol, 123, pp. 323-333, 1996. 
24.W. Irber, H. J. Forster, L. Hech, P. Moller and G. Mortteani, Experimental, geochemical, mineralogical and oxygen isotope constrain in the late magmatic history of the Fichtelgebirge granites (Germany).Geol Rdesch 86, pp.110-124, 1997.

25.P. Cerny and D. M. Burt, Paragenesis, and geochemical evolution of micas in granitic pegmatites, in Bailey, S. W., ed., Micas: Mineralogical Society of America, Reviews in Mineralogy, v. 13, pp. 257- 297, 1984.

26.A. Miyashiro, Classification, characteristics and origin of ophiolites. J. Geol., vol. 83, pp. 249-281, 1975.

27.A. Gerdes, G. Worner and A. Henk, Post collisional granite generation and HT - LP metamorphism by radiogenic heating: the Variscan South Bohemian Batholith. J. of the Geological Society of London. 157, pp. 577$587,2000$. 